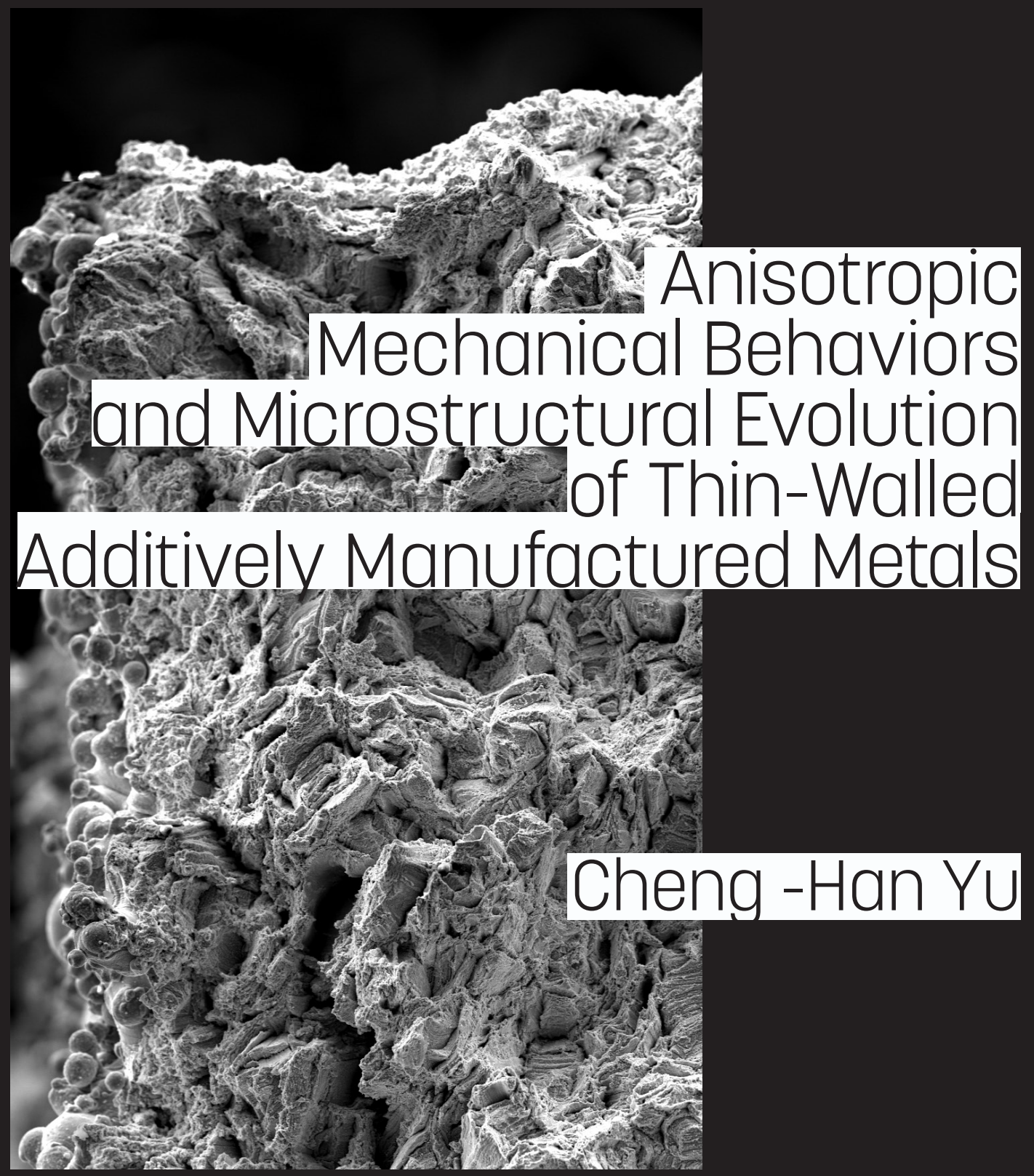


Linköping Studies in Science and Technology

Licentiate Thesis No. 1884

\title{
Anisotropic mechanical behaviors and microstructural evolution of thin-walled additively manufactured metals
}

\author{
Cheng-Han $\mathrm{Yu}$
}


Opponent: Dr. Joe Kelleher, ISIS Neutron and Muon Source, UK Date: October 9, 2020

Location: ACAS, Linköping University

(C) Cheng-Han $\mathrm{Yu}$

ISBN 978-91-7929-811-1

ISSN 0280-7971

Printed by LiU-Tryck 2020 


\section{Abstract}

Additive manufacturing (AM), also known as 3D printing, is a concept and method of a manufacturing process that builds a three-dimensional object layer-by-layer. Opposite to the conventional subtractive manufacturing, it conquers various limitations on component design freedom and raises interest in various fields, including aerospace, automotive and medical applications. This thesis studies the mechanical behavior of thin-walled component manufactured by a common AM technique, laser powder bed fusion (LPBF). The studied material is Hastelloy $\mathrm{X}$, which is a $\mathrm{Ni}$-based superalloy, and it is in connection to a component repair application in gas turbines. The influence of microstructure on the deformation mechanisms at elevated temperatures is systematically investigated. This study aims for a fundamental and universal study that can apply to different material grades with FCC crystallographic structure.

It is common to find elongated grain and subgrain structure caused by the directional laser energy input in the LPBF process, which is related to the different printing parameters and brands of equipment. This thesis will start with the study of scan rotation effect on stainless steel 316L in an EOS M290 equipment. The statistic texture analysis by using neutron diffraction reveals a clear transition when different level of scan rotation is applied. Scan rotation of $67^{\circ}$ is a standard printing parameter with intention to lower anisotropy, yet, the elongated grain and cell structure is still found in the as-built microstructure. Therefore, the anisotropic mechanical behavior study is carried out on the sample printed with scan rotation of $67^{\circ}$ in this thesis.

Thin-walled effects in LPBF are investigated by studying a group of plate-like HX specimens, with different nominal thicknesses from $4 \mathrm{~mm}$ down to $1 \mathrm{~mm}$, and a reference group of rod-like sample with a diameter of $18 \mathrm{~mm}$. A texture similar to Goss texture is found in rod-like sample, and it becomes $<011>/ /$ BD fiber texture in the $4 \mathrm{~mm}$ specimen, then it turns to be $<001>$ fiber texture along the transverse direction (TD) in the $1 \mathrm{~mm}$ specimen. Tensile tests with the strain rate of $10^{-3}$ $\mathrm{s}^{-1}$ have been applied to the plate-like specimens from room temperature up to 
$700{ }^{\circ} \mathrm{C}$. A degradation of strength is shown when the sample becomes thinner, which is assumed to be due to the overestimated load bearing cross-section since the as-built surface is rough. A cross-section calibration method is proposed by reducing the surface roughness, and a selection of proper roughness parameters is demonstrated with the consideration of the calculated Taylor's factor and the residual stress. The large thermal gradient during the LPBF process induces high dislocation density and strengthens the material, hence, the LPBF HX exhibits better yield strength than conventionally manufactured, wrought HX, but the work hardening capacity and ductility are sacrificed at the same time.

Two types of loading condition reveal the anisotropic mechanical behavior, where the vertical and horizontal tests refer to the loading direction being on the BD and TD respectively. The vertical tests exhibit lower strength but better ductility that is related to the larger lattice rotation observed from the samples with different deformation level. Meanwhile, the elongated grain structure and grain boundary embrittlement are responsible for the low horizontal ductility. A ductile to brittle transition is traced at $700{ }^{\circ} \mathrm{C}$, so a further study with two different slow strain rates, $10^{-5} \mathrm{~s}^{-1}$ and $10^{-6} \mathrm{~s}^{-1}$, are carried out at $700{ }^{\circ} \mathrm{C}$. Creep damage is shown in the slow strain rates testing. Deformation twinning is found only in the vertical tests where it forms mostly in the twin favorable $<111>$ oriented grain along the LD. The large lattice rotation and the deformation twinning make the vertical ductility remain high level under the slow strain rates. The slow strain rate tensile testing lightens the understanding of creep behavior in LPBF Ni-based superalloys.

In summary, this thesis uncovers the tensile behavior of LPBF HX with different variations, including geometry-dependence, temperature-dependence, crystallographic texture-dependence and strain rate-dependence. The generated knowledge will be beneficial to the future study of different mechanical behavior such as fatigue and creep, and it will also enable a more robust design for LPBF applications.

Keyword: hot tensile testing, slow strain rate tensile testing, creep, anisotropy, crystallographic texture evolution, deformation twinning 


\section{Populärvetenskaplig sammanfattning}

Additiv tillverkning, eller 3D-utskrifter, är tillverkningsmetoder där man skapar ett tredimensionellt objekt genom att tillföra material lager för lager. Till skillnad från konventionella avverkande tillverkningsmetoder elimineras många geometriska begränsningar vilket ger större designfrihet och metoderna har därför väckt stort intresse inom en rad olika områden, inklusive flyg-, fordons- och medicinska tillämpningar. I denna avhandling studeras mekaniska egenskaper hos tunnväggiga komponenter tillverkade med en vanligt förekommande laserbaserad pulverbädds-teknik, laser powder bed fusion (LPBF). Det studerade materialet är Hastelloy X, en Ni-baserad superlegering som är vanligt förekommande för både nytillverkning och reparation av komponenter för gasturbiner. Inverkan av mikrostruktur på deformationsmekanismerna vid förhöjda temperaturer undersöks systematiskt. Detta arbete syftar till att ge grundläggande och generisk kunskap som kan tillämpas på olika materialtyper med en kubiskt tätpackad (FCC) kristallstruktur.

Det är vanligt att man hittar en utdragen kornstruktur orsakad av den riktade tillförseln av laserenergi i LPBF-processen, vilket kan relateras till olika processparametrar och kan variera mellan utrustningar från olika leverantörer. Denna avhandling inleds med studien av effekten av scanningsstrategi vid tillverkning av rostfritt stål 316L i en EOS M290-utrustning. En statistisk texturanalys med hjälp av neutrondiffraktion påvisar en tydlig övergång mellan olika mikrostrukturer när olika scanningsstrategier tillämpas. En scanningsrotation på 67 mellan varje lager är en typisk standardinställning med avsikt att sänka anisotropin i materialet, dock finns den utdragna kornstrukturen oftast kvar. I denna avhandling studeras därför de anisotropa egenskaperna hos material tillverkade med 67 scanningsrotation.

Effekten av tunnväggiga strukturer i LPBF undersöks genom att studera en uppsättning platta HX-prover, med olika nominella tjocklekar från $4 \mathrm{~mm}$ ner till $1 \mathrm{~mm}$, samt en referensgrupp med cylindriska prov med en diameter på 18 mm. Kristallografisk textur som liknar den av Goss-typ återfinns i de cylindriska 
proverna vilket gradvis övergår från en fibertextur med $<011>\mathrm{i}$ byggriktningen för $4 \mathrm{~mm}$-proven till en fibertextur med $<001>$ i tvärriktningen för $1 \mathrm{~mm}$-proven. Dragprovning med en töjningshastighet på $10^{-3} \mathrm{~s}^{-1}$ har utförts på de platta provstavarna från rumstemperatur upp till $700{ }^{\circ} \mathrm{C}$. En sänkning av styrkan uppvisas när proven blir tunnare, vilket kan antas bero på att det lastbärande tvärsnittet överskattas på grund av den grova ytan. En metod för tvärsnittskalibrering föreslås genom att kompensera för ytråheten, och valet av lämplig ytfinhetsparameter motiveras med hänsyn till den beräknade Taylor-faktorn och förekomsten av restspänningar. Den stora termiska gradienten som uppstår för LPBF-processen inducerar en hög dislokationstäthet vilket höjer materialets styrka och följaktligen uppvisar LPBF HX högre sträckgräns än konventionellt tillverkad, smidda HX, men förmågan till deformationshårdnande samt duktiliteten i materialet sänks samtidigt.

Tester utförda i två olika belastningsriktningar, vertikalt respektive horisontellt mot byggriktningen, demonstrerar det anisotropiska mekaniska beteendet. De vertikala testerna uppvisar lägre hållfasthet men bättre duktilitet vilket kan relateras till en större benägenhet för kristallstukturen att rotera när deformationsgraden ökar. Samtidigt är den utdragna kronstukturen ansvarig för den lägre duktiliteten för de horisontella proverna. En övergång från ett duktilt till ett mer sprött beteende noterades vid $700{ }^{\circ} \mathrm{C}$, och därför initierades ytterligare en studie där tester med två lägre töjningshastigheter, $10^{-5} \mathrm{~s}^{-1}$ och $10^{-6} \mathrm{~s}^{-1}$, utfördes vid $700{ }^{\circ} \mathrm{C}$. Det kan noteras att krypskador återfinns i tester med en långsam deformationshastighet och deformationstvillingar uppstår endast i de vertikala provstavarna där det främst bildas tvillingar i korn orienterade med $<111>$ riktningen längs belastningsriktningen. Den stora förmågan till rotation i kristallstrukturen och deformationstvillingarna bidrar till att den vertikala duktiliteten förblir hög även i testerna med en låg deformationshastighet. Testerna med en långsam draghastighet bidrar därför till en bättre förståelse av krypbeteendet i LPBF Nibaserade superlegeringar.

Sammanfattningsvis så bidrar denna avhandling till bättre förståelse av de mekaniska egenskaperna hos LPBF HX i olika utföranden och förhållanden, inklusive geometriberoende, temperaturberoende, deformationshastighetsberoende samt inverkan av kristallografisk textur. Den genererade kunskapen kommer att vara till stor nytta vid fortsatta studier av olika mekaniska egenskaper som utmattning och kryp, samt bidrar till att möjliggöra en mer robust design för LPBF-tillämpningar.

Nyckelord: Varmdragprov, Dragprov med låg töjningshastighet, kryp, anisotropi, kristallografisk textur, deformationstvillingar 


\section{Acknowledgements}

This research is financially supported by the Swedish Governmental Agency for Innovation Systems (Vinnova grant 2016-05175) and the Center for Additive Manufacturing -metal $\left(C A M^{2}\right)$. The support also comes from AFM at Linköping University and the faculty grant SFO-MATLiU2009-00971. Acknowledgment goes to Agora Materiae, a multidisciplinary doctoral program at Linköping University,Sweden.

It has been a crazy time when I was preparing this Licentiate thesis since COVID-19 spread out all over the world. I am grateful that everyone within my working environment manages to stay in one piece, so this work can be conducted smoothly.

Firstly, I would like to thank my main supervisor, Johan Moverare, for offering me a chance to explore this interesting study field. Your guidance in our discussions and the freedom you give me to develop the project are highly appreciated. I would also like to acknowledge my co-supervisor, $\mathrm{Ru}$ Ling Peng, for your valuable input especially in microstructure characterization and neutron related discussion. I enjoy the discussions with both of you, especially when different ideas clash and generate another way of thinking. Your passion and dedication to research set up a great model that I will be always look up to .

Gratitude goes to everyone who has been involved in my research work, particularly, Vladimir Luzin from ANSTO in Sydney for neutron diffraction measurement, Alexander Leicht from Chalmers university in Göteborg for stainless steel 316L collaboration, Maximilian Sprengel from BAM in Berlin for residual stress measurement, Robert Boyd from IFM in Linköping Univeristy for TEM trainning, Mattias Calmunger from the same division for wrought HX study. Håkan Brodin and Jan-Erik Lundgren from Siemens Energy AB in Finspång are acknowledged for providing the studied materials and the valuable discussion.

I would like to thank all my colleagues at the Division of Engineering Materials, Linköping University, the positive working atmohphere and the different discussion within the group are extremely helpful. Special acknowledgement goes to our 
administrator, Ingmari Hallkvist, for taking care of each detail, and also to the technical support from Rodger Romero Ramirez and Patrik Härnman, my PhD life would not go so well without you. I would like to acknowledge the AM group meeting, it is always interesting to see ideas from different perspectives. I would also like to thank Dunyoung Deng, Jinghao Xu and Prabhat Pant, for the scientific discussion and also for all the interesting little talks during different trips.

A great thank to my family in Taiwan. It is a bittersweet period of my stay in Sweden for both the master and PhD studies. I know it is a hard time to see me be away from all of you for years, but you still support my decision in any way. The happiness and health of everyone are the biggest support to me. I am also grateful to my friends for the all chats that make me laugh like an idiot on the road.

Finally, I would like to thank my love, Che Fen, for your support in all the years, especially maintaining the long-distance relationship to Taipei and Paris. Your creative thinking always lightens my life, and I will always remember the precious time when we had Alpa. The thesis could not be done without your hand-brewed coffee every morning.

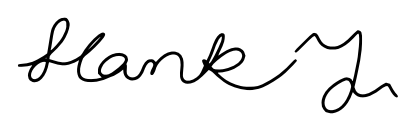

Hank Yu

Linköping, October 2020 


\section{List of papers}

The papers related to this Licentiate thesis are as follow:

\section{Appended papers}

I. A. Leicht, C. H. Yu, V. Luzin, U. Klement, and E. Hryha, "Effect of scan rotation on the microstructure development and mechanical properties of $316 \mathrm{~L}$ parts produced by laser powder bed fusion," Materials Characterization, vol. 163, p. 110309, 2020.

In this paper paper, Cheng-Han Yu contributes the statistic texture analysis by using neutron diffraction. The main contributor is Alexander Leicht at Chalmers University, Göteborg, Sweden.

II. C.-H. Yu, R. L. Peng, J.-E. Lundgren, and J. Moverare, "Anisotropic mechanical properties of thin-walled Hastelloy X manufactured by laser powder bed fusion," European Congress and Exhibition on Powder Metallurgy, 2019.

III. C.-H. Yu, R. L. Peng, V. Luzin, M. Sprengel, M. Calmunger, J.-E. Lundgren, H. Brodin, A. Kromm, J. Moverare, "Thin-wall effect and anisotropic deformation mechanisms of an additively manufactured Ni-based superalloy," submitted manuscript.

IV. C.-H. Yu, R. L. Peng, H. Brodin, and J. Moverare, "Anisotropic deformation and fracture mechanisms of an additively manufactured Ni-based superalloy," in TMS Superalloys 2020.

In the appended papers II-IV, Cheng-Han Yu is the main contributor, including mechanical testing, microstructure analysis and manuscript writing, under the supervision of Johan Moverare and Ru Lin Peng. The studied materials are provided by Siemens Energy AB, Finspång, Sweden. The texture 
measurement by using neutron diffraction is contributed by Vladimir Luzin at Australian Nuclear Science and Technology Organization (ANSTO), Sydney, Australia. The residual stress measurement is contributed by Maximilian Sprengel and Arne Kromm at Bundesanstalt für Materialforschung und -prüfung (BAM), Berlin, Germany. The mechanical testing of wrought Hastelloy $X$ is contributed by Mattias Calmunger at Linköping University. 
Additive Manufacturing

Building Direction

Computer Aided Design

Critical Resolved Shear Stress

Dynamic Strain Aging

Electical Discharge Machining

Electron Backscatter Diffraction

Electron Beam Melting

Face-Centered Cubic

Grain growth Direction

Hastelloy X

Hexagonal Close-Packed

Inverse Pole Figure

Laser Powder Bed Fusion

Light Optical Microscope

Loading Direction

Orientation Distribution Function

Pole Figure

Powder Bed Fusion

Scanning Electron Microscope

Slow Strain Rate Testing

Transmission Electron Microscope

Transverse Direction

Time-Temperature-Transformation

Topological Close-Packed

Ultimate Tensile Strength

Wall Direction
AM

BD

CAD

CRSS

DSA

EDM

EBSD

EBM

FCC

GD

HX

HCP

IPF

LPBF

LOM

LD

ODF

PF

PBF

SEM

SSRT

TEM

TD

TTT

TCP

UTS

WD 

Abstract

Acknowledgements vii

List of papers $\quad$ ix

Abbreviations $\quad$ xi

I Background and Theory 1

1 Introduction $\quad 3$

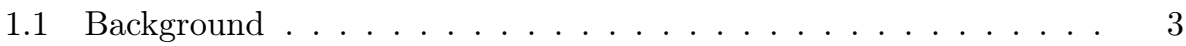

1.2 Aims and research questions . . . . . . . . . . . . . . 4

1.3 Outline .......................... 4

2 Additive manufacturing $\quad \mathbf{7}$

2.1 Additive manufacturing processes . . . . . . . . . . . . . . . 7

2.2 Materials . . . . . . . . . . . . . . . . . . . . . 9

2.2.1 Solid solution strengthened alloy . . . . . . . . . . . . . . 9

2.3 Typical microstructure for LPBF . . . . . . . . . . . . . . . . . . . 11

2.4 Thin-walled structure . . . . . . . . . . . . . . . . . . 15

2.4.1 Thickness and height-dependent . . . . . . . . . . 16

2.4 .2 Surface roughness . . . . . . . . . . . . . 17

3 Deformation and fracture mechanisms $\quad 19$

3.1 Anisotropic mechanical behaviors . . . . . . . . . . . . . . . . . . 19

3.2 Grain morphology effect . . . . . . . . . . . . . . . . 20

3.3 Dislocation movement and texture strengthening . . . . . . . . 21 
3.4 Texture evolution . . . . . . . . . . . . . . . . . . . 24

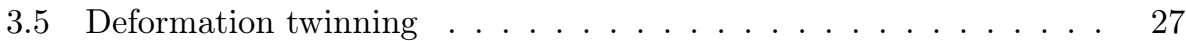

3.6 Creep damage . . . . . . . . . . . . . . . . . . . . . . . . . . . . . 28

4 Experimental methods 31

4.1 Laser Powder Bed Fusion . . . . . . . . . . . . . . . . . . . . 31

4.2 Mechanical test . . . . . . . . . . . . . . . . . 31

4.3 Microstructure characterization . . . . . . . . . . . . . . . 32

4.3.1 Light optical microscope . . . . . . . . . . . . . . . . . . 32

$4.3 .2 \quad$ Scanning electron microscope . . . . . . . . . . . . . . . . 32

4.3.3 Transmission electron microscope . . . . . . . . . . . . . 33

4.4 Neutron diffraction . . . . . . . . . . . . . . . . . 33

4.5 Roughness determination $\ldots \ldots \ldots \ldots \ldots$

5 Summary of the appended papers $\quad 35$

6 Conclusion 39

$\begin{array}{lll}7 & \text { Future work } & 41\end{array}$

Bibliography $\quad 43$

$\begin{array}{ll}\text { II Publications } & 51\end{array}$

Paper I $\quad 53$

$\begin{array}{ll}\text { Paper II } & 65\end{array}$

$\begin{array}{ll}\text { Paper III } & 73\end{array}$

$\begin{array}{ll}\text { Paper IV } & 103\end{array}$ 


\section{Part I}

\section{Background and Theory}



CHAPTER 1

\section{Introduction}

\subsection{Background}

Additive Manufacturing (AM), also known as 3D printing, has recently raised high interest in various applications in virtue of potential advantages such as component design freedom and manufacturing energy efficiency. In an AM process, the component is built layer-by-layer guided by 3D computer aided design (CAD) model, which breaks the geometrical limitation in the conventional manufacturing, and it enables a complex geometry to be fabricated in one-step. The concept of AM was brought up in the 70's and executed in the 80's, and it was started with the Stereolithography process on polymer materials [1]. The AM in metallic materials began with the sintering or melting by laser-based techniques from 90's, and after a long period of development, various processes became relatively applicable in 10 's. For decades it has been called "rapid prototyping", but thanks to the successful development of AM techniques in the recent years, AM components become functional and able to be used as critical parts in different applications, such as aerospace, automotive and medical surgery [2]. The concept of mass production has dominated over decades, but the idea of mass customization gradually takes the place of it in the recent industrialization revolution. Without a doubt, AM will play as a "game changer" in mass customization, and it is expected to prevail in a wide variety of applications. However, the functionality needs to pass a complete examination and fulfill standard requirements, therefore, this thesis systematically investigates the mechanical behavior and deformation mechanism of LPBF materials with the focus on the anisotropy and thin-wall effects.

This PhD study is within the framework of CAM2, a competence center for additive manufacturing of metals funded by Vinnova, and it includes seven different research areas. This work is under the research area of material behavior and 
design of AM components, and a specific investigation has been carried out on the anisotropic material properties and thin-walled structure of a Ni-based superalloy for high temperature applications. An application connected to this study is the burner tip repair in gas turbines [3], in which the tip can be built directly on the remained nozzle after the worn part being removed instead of manufacturing the entire component. The manufacturing and machining processes of Ni-based superalloy require high energy consumption, so an entire component remanufacturing is definitely a waste of energy and material. The AM process produces the part directly with one step, and the strength of energy efficiency makes AM a great potential for the development of sustainable environment.

\subsection{Aims and research questions}

A general aim of this thesis is to generate knowledge of mechanical behavior of AM materials and bring AM a step further from prototyping toward functional component. In addition, this thesis aims for a fundamental and universal study that applies to different material grades with a Face-Centered Cubic (FCC) crystallographic structure and manufactured by Laser powder bed fusion (LPBF). A detailed plan is to uncover the tensile behaviors of Hastelloy X, a Ni-based superalloy, with different variations, including geometry-dependence, temperaturedependence, strain-rate dependence and crystallographic texture-dependence. To investigate the mechanisms behind the tensile behaviors, microstructure study and statistic texture analysis are carried on the as-built and deformed materials.

The following research questions will first address the commonly found features in AM materials, and then find the mechanisms for the material behaviors.

1. What are the typical microstructure and anisotropic mechanical properties in LPBF materials?

2. How does the microstructure and mechanical behavior evolve when it comes to thin-walled structure in LPBF?

3. How does the mechanical behavior of LPBF FCC materials respond at elevated temperatures and different strain rates?

4. Based on the questions above, what are the mechanisms for anisotropic mechanical behaviors and how does it relate to elongated grain and subgrain structure?

\subsection{Outline}

The thesis is structured into two parts. Part $\mathbf{I}$ is the Background and Theory, and it consists of seven chapters. It starts with a brief introduction of the $\mathrm{PhD}$ research project, followed by the addressed research questions that structure this Licentiate thesis. A general presentation of additive manufacturing from the points of view of process, limited material applicability, microstructure and thin-walled structure 
is brought up. Right after that, the mechanical behaviors and several important theories of deformation mechanism are given. Then, the highlights of the related papers are summarized, responding to the research questions mentioned in the beginning. Finally, the conclusions that answer the research question are given in four themes. Part II is the Publications, which presents the main part of the $\mathrm{PhD}$ research so far. 


\section{CHAPTER 2}

Additive manufacturing

\subsection{Additive manufacturing processes}

According to the standard, ISO/ASTM52900-15, the AM processes are defined in seven categories,

- Vat photopolymerization

- Material jetting

- Binder jetting

- Powder bed fusion

- Material extrusion

- Directed energy deposition

- Sheet lamination

Among above, powder bed fusion (PBF) is a commonly used technique for metallic materials, and there are two major categories of PFB depending on different input energy, laser source (laser powder bed fusion, LPBF) or electron beam source (electron beam melting, EBM). The two techniques share similarity of working principles that the input energy melts the powders at the top surface of the powder bed in the commanded area and the component is built layer by layer, but the detailed parameters are different. For example, the used powder in LPBF is smaller than EBM, the vacuum chamber and heating is need in EBM, and the support structure is required in $\mathrm{LPBF}[4]$. 


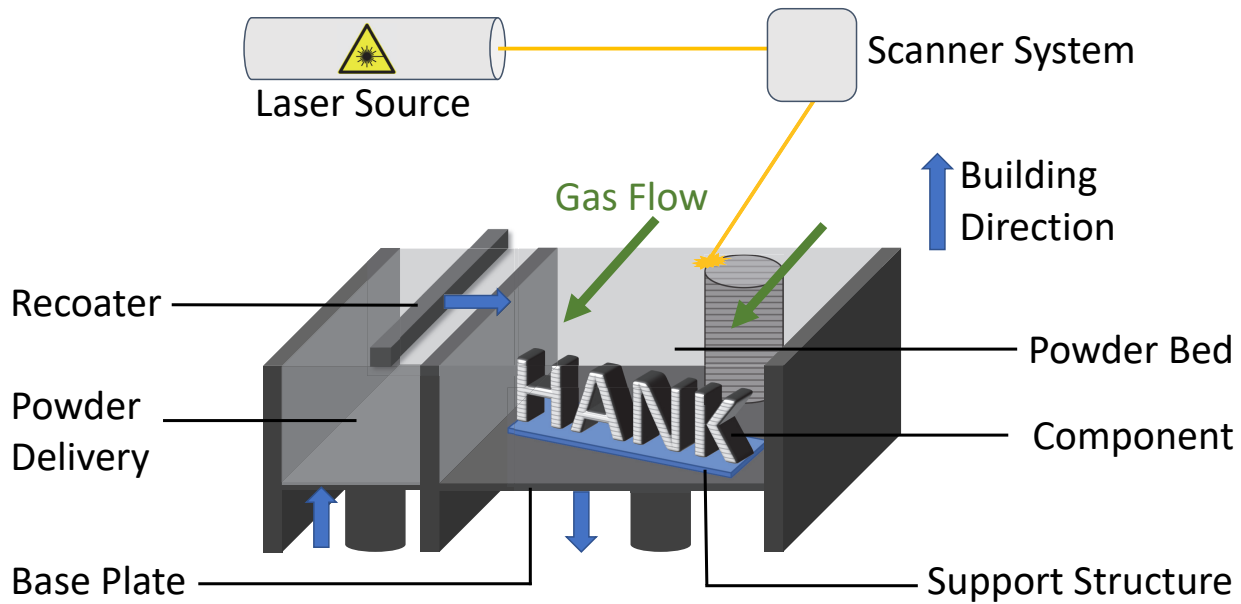

Figure 2.1. Schematic illustration of laser powder bed fusion.

This study will focus on LPBF and a simplified schematic illustration is demonstrated in Figure 2.1. It is a continuously circular process where the laser source melts along the designed pattern on the top layer of the powder bed, then the base plate lowers down the entire powder bed, and the recoater brings a new layer of powder from the powder delivery to the powder bed for the next round of laser melting. For each layer, the laser moves linearly and parallelly along the same direction, melting the powder in the region commanded by the designed pattern. The designed pattern can be briefly categorized to two types, hatching (the region of main body) and contouring (the linear boundary), and the input energy density is different between each other. Scan rotation corresponds to the directional change of the moving laser between consecutive layers. Scan rotation of $67^{\circ}$ is a commonly used parameter in the standard process, which means that the laser moving direction will continuously shift $67^{\circ}$ after each layer and the center of powder bed is approximately the rotation center. During the printing process, an inert gas flow is applied in the direction perpendicular to the recoater moving direction, where the proper parameters can optimize the interaction between the ambient environment and the melt pool [5], and it further improves the quality of the component such as lower amount of porosity, better surface roughness and mechanical properties [6,7]. The support structure in Figure 1 is only placed between the component and base plate, but in a real case the support structure is often designed beneath the fragile part, for instance, the overhang. The support structure is for the prevention of distortion during the printing process, the position and geometry of the support structure can be suggested by the software and decided by the designer $[8,9]$.

Various process parameters and scanning strategies can be tuned for the desired material properties, for example, laser moving speed, hatch distance, layer thickness and scan rotation [10-14]. The influence of scan rotation for texture control will be discussed later on in this chapter. 


\subsection{Materials}

The material for this study is Hastelloy X (HX), a Ni-Cr-Fe-Mo alloy, as a material grade of Ni-based superalloy it exhibits excellent corrosion resistance and mechanical properties for high temperature applications [15]. HX exists as a single phase of austenitic $\gamma$ matrix at as-built state, which is a FCC crystallographic structure, and the nominal chemical composition is listed in Table 2.1.

\begin{tabular}{|c|c|c|c|c|c|c|c|}
\hline Ni & $\mathbf{C r}$ & $\mathbf{F e}$ & Mo & W & Co & C & Si \\
\hline Bal. & $20.5-23$ & $17-20$ & $8-10$ & $0.2-1$ & $0.5-2.5$ & $\leq 0.1$ & $\leq 1$ \\
\hline Mn & S & $\mathbf{P}$ & $\mathbf{B}$ & Se & $\mathbf{C u}$ & $\mathbf{A l}$ & $\mathbf{T i}$ \\
\hline$\leq 1$ & $\leq 0.03$ & $\leq 0.04$ & $\leq 0.01$ & $\leq 0.005$ & $\leq 0.5$ & $\leq 0.5$ & $\leq 0.15$ \\
\hline
\end{tabular}

Table 2.1. Nominal composition of EOS NickelAlloy HX, in wt\%

Since each alloy requires a development of specific printing parameters for its own, there are only limited numbers of printable material grades in the state-ofthe-art LPBF and EBM techniques. The printability depends on various factors, including dimension accuracy, composition variation, lack of fusion defects and more, and multiple material properties of each composition need to be taken in consideration, for example, thermal expansion coefficient, diffusion coefficient and thermal conductivity [16]. For Ni-based superalloy, the printability highly depends on the amount of $\gamma^{\prime}$ phase [17], which is an ordered coherent intermetallic precipitate with a chemical formula $\mathrm{Ni}_{3}(\mathrm{Al}, \mathrm{Ti}) \cdot \gamma^{\prime}$ precipitation is an important strengthening mechanism for Ni-based superalloy, especially for good creep resistance it requires $40-80 \%$ volume fraction of $\gamma^{\prime}[18]$. However, the higher content of $\mathrm{Al}$ and $\mathrm{Ti}$ reduces the weldability of an alloy and it will be prone to form defects by various mechanisms, such as solidification cracking, liquation cracking and strain-age cracking [17], therefore, the content of $\mathrm{Al}$ and $\mathrm{Ti}$ is an indication of the printability. As a result, it is difficult to print alloys with high volume of $\gamma^{\prime}$, for instance, Inconel 738 [19, 20], CM247LC [21], CMSX-4 [22, 23] and René N5 [24]. On the other hand, the solid solution strengthened alloys such as Inconel 625 and Hastelloy X, and the $\gamma^{\prime \prime}$ strengthened alloy like Inconel 718, exhibit better printability. Given the good printability of HX, it is reasonable to assume that the as-built specimens are nearly defect free, so the influence such as porosity and lack of fusion is not within concern when it comes to the discussion of deformation mechanism in this study.

\subsubsection{Solid solution strengthened alloy}

HX is a majorly solid solution strengthened alloy, in which the solute atoms induce lattice distortion and create coherent strain field to hinder the dislocation movement [25]. Each element contributes differently to the solid solution strengthening where the eventual strengthening can be quantified by equation (2.1) [26-28], 


$$
\Delta \sigma=\sum_{i} \frac{d \sigma}{\sqrt{d c_{i}}} \sqrt{c_{i}}
$$

where $\mathrm{c}$ is the solute concentration and $\frac{d \sigma}{\sqrt{d c_{i}}}$ is a strengthening coefficient varying with different element. The yield strength correlates well with the solid solution strengthening, and the strengthening coefficient can be obtained by fitting the Feltham equation to the experimental data [27]. With the consideration of ternary and higher order of alloy system, the strengthening coefficients in the nickel $\gamma$ matrix of the alloyed element in HX are shown in Table 2.2, where Mo and $\mathrm{C}$ exhibit high strengthening capability.

\begin{tabular}{|c|c|c|c|c|c|c|c|c|c|c|c|}
\hline Element & Fe & Cr & Mo & W & Co & C & Si & Mn & Co & Al & Ti \\
\hline$\frac{d \sigma}{\sqrt{d c_{i}}}$ & 153 & 337 & 1015 & 977 & 39.4 & 1061 & 275 & 448 & 86.7 & 225 & 775 \\
\hline
\end{tabular}

Table 2.2. Solid solution strengthening coefficients of alloyed element in nickel $\gamma$ matrix, $\frac{d \sigma}{\sqrt{d c_{i}}}$.

Precipitation strengthening of the various secondary phases in $\gamma$ matrix is an important strengthening mechanism in Ni-based superalloys [29]. The alloys with formation of intermetallic compounds, $\gamma^{\prime}$ and $\gamma^{\prime \prime}$, are classified as the principal precipitation strengthened material group, which can fulfil high requirement of mechanical properties at elevated temperatures. For the material group that is essentially solid solution strengthened, the formation of carbides provides additional but limited strengthening. The formation of carbides at grain boundaries stabilizes the local grain boundaries against the excessive shear, which is a common case, meanwhile, the formation of carbides within grains can also strengthen the material via dispersion hardening.

No precipitation is shown in the as-built state of HX [30], but with different heat treatment conditions there are four types of precipitation being observed [31, 32 ], $\mathrm{M}_{23} \mathrm{C}_{6}, \mathrm{M}_{6} C, \sigma$ and $\mu$. The time-temperature-transformation (TTT) diagram of conventionally manufactured $\mathrm{HX}$ can be found in Figure 2.2. $\mathrm{M}_{23} \mathrm{C}_{6}$ and $\mathrm{M}_{6} C$ are carbides with $\mathrm{FCC}$ crystal structure where it is common to find $\mathrm{M}_{23} \mathrm{C}_{6}$ in Cr-rich region and $\mathrm{M}_{6} C$ in Mo-rich region. $\sigma$ and $\mu$ are so-called topological closepacked (TCP) phases, and both are detrimental to mechanical properties due to the incoherent crystal structures. 


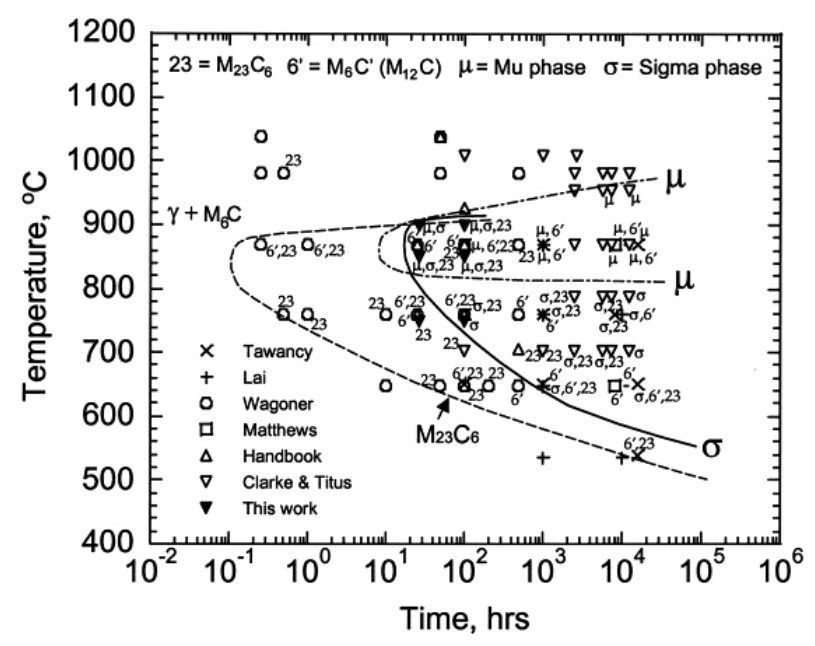

Figure 2.2. TTT diagram of conventionally manufactured Hastelloy $\mathrm{X}$ reprinted from J. Zhao et al. [31]. Four different precipitations are observed and labeled, including $\mathrm{M}_{23} \mathrm{C}_{6}, \mathrm{M}_{6} C, \sigma$ and $\mu$.

\subsection{Typical microstructure for LPBF}

The directional and concentrated laser energy input induces high thermal gradient, guiding the continuous grain growing approximately along the building direction (BD). As a result, elongated grain structure and cell structure are common features in $\mathrm{LPBF}$, which can be found from different perspectives in the scanning electron microscope (SEM), electron backscatter diffraction (EBSD) and light optical microscope (LOM) images in Figure 2.3. In the lower magnification, a roughly elongated grain structure is shown from the side view and an equiaxed grain structure is shown from the top view, and a cell structure exists within the high angle grain boundaries $\left(>10^{\circ}\right)$ under the further higher magnification. The cell structure consists of primary dendrite arms formed during the rapid cooling process. The grain growth direction (GD) of the dendrite arm follows the energy-favorable crystallographic $<001>$ direction, hence, the general texture behavior can be estimated from the cell structure. Different input energy source and printing parameters influence the grain growth process and lead to different final texture [33-35]. Take EBM for a comparison, a strong $<001>$ texture component along the BD is commonly found in EBM materials, however, different textures along the BD in LPBF materials are reported in the literature [36-40]. The influence of scanning rotation and the geometrical effect will be discussed later in this chapter. 
(a)

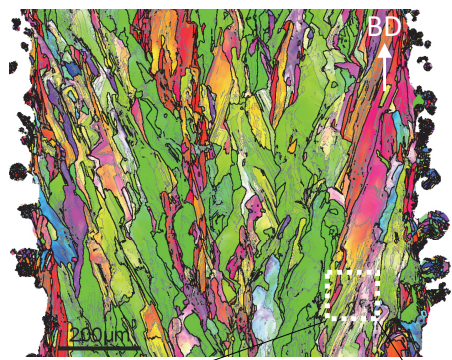

(c)

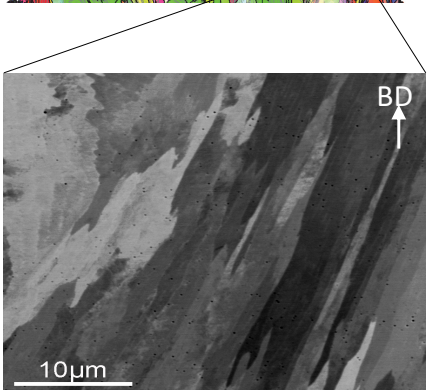

(b)

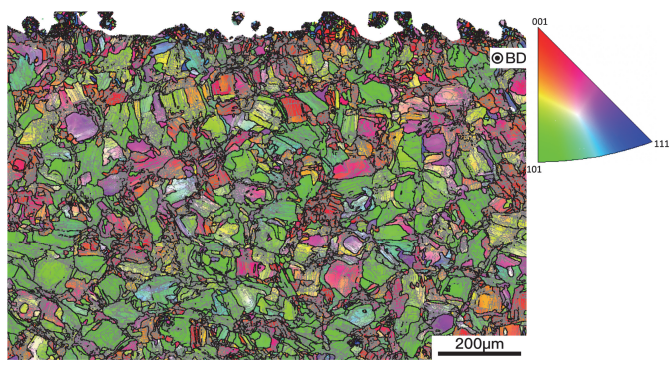

(d)

Building direction (BD)

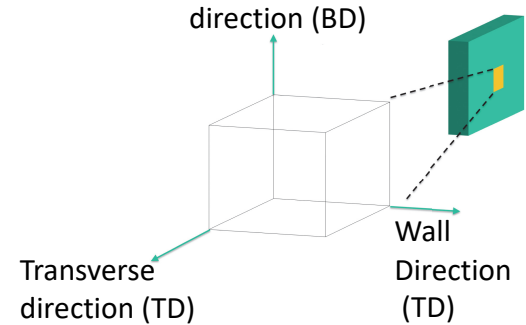

(e)

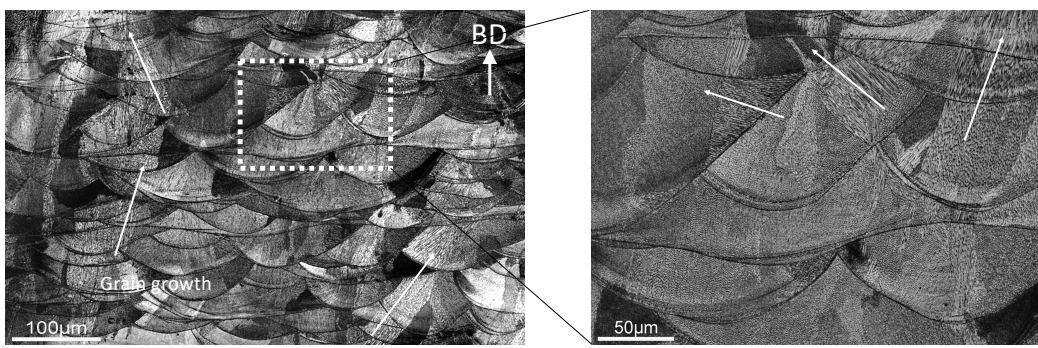

Figure 2.3. The as-built microstructure of LPBF HX. The coordinate system in this study is given here. (a) EBSD grain orientation mapping in the side-view where the BD is along the vertical direction. The rough as-built surfaces are at the left and right end. The color legend corresponds to the BD. The black lines refer to $>10^{\circ}$ grain boundaries and the gray lines refer to $>2^{\circ}$ grain boundaries. (b) EBSD grain orientation mapping in the top-view where the BD is out-plane, and the surface is at the top end. The color legend and grain boundaries settings are the same as in (a). (c) A SEM image from the selected area in (a), showing the elongated cell structure. (d) The coordinate system of the sample, where the building direction (BD), wall direction (WD) and transverse direction (TD) are defined. The different thickness is the width variation on the wall direction. (e) Melt pool structure from LOM images. The grain growth directions are labeled with white arrows by the elongated direction of cell structure. A selected area showing the relation between the grain growth and melt pool boundaries.

Melt pool structure is a common feature in LPBF generated due to the localization of concentrated laser energy input. Melt pool structure can be revealed after being electro-etched, hence, it suggests that element segregation takes place around melt pool boundaries. As shown in Figure 2.3e, the sizes of melt pools are 
not identical. The size can be larger than the powder layer thickness brought by the recoater in each printing step, pointing out that the laser can melt through multiple powder layers while passing the surface of powder bed. In addition, the grain growth can continuously pass through multiple melt pool boundaries, and the GD constantly changes the direction. The shape and curvature of melt pool can be an indication of general texture behavior since the GD varies in different melt pool morphology [41, 42], see the schematic illustration in Figure 2.4. A strong $<001>$ texture can be found in the shallow melt pool as the GD is mostly along the BD. For the deeper melt pool, the deviation of the GD from the BD becomes larger, and it leads to a more random texture. However, the cases in Figure 2.4 are only valid when the melt pool morphology are identical over a large area. Various printing parameters can influence the melt pool morphology, for instance, the laser energy density and scan rotation. The melt pool with various sizes and morphology shown in Figure 2.3e is a good example for the case that the scan rotation of $67^{\circ}$ was applied. The $67^{\circ}$ scan rotation is one of the standard process in an EOS equipment, and it serves the purpose for reaching isotropic material properties by increasing the randomness of heat flow [11]. A further discussion with the respect to grain growth, melt pool boundaries and microstructure can be found in Paper III and Paper IV.

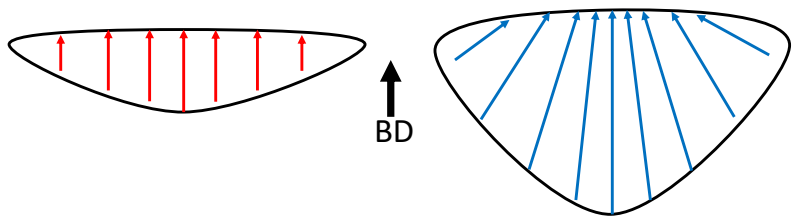

Figure 2.4. Schematic illustration of melt pool structures with different morphology. The blue and red arrows refer to the grain growth with the preferable $<001>$ crystallographic direction.

The microstructure of LPBF materials is far from homogeneous compared to conventional manufactured materials, therefore, the statistic texture analysis is a good way to make fair comparison among different printing parameters. The effect of different scan rotation on a LPBF stainless steel 316L is shown in Figure 2.5 and Figure 2.6 [12]. In Figure 2.5, a strong $<011>$ texture component is found in the sample with no scan rotation being applied, and the asymmetrical intensity between the transverse direction (TD) and the wall direction (WD) shows the similarity with the Goss texture that is commonly found in the rolling steel [43]. When the scan rotation is applied, the texture become weaker and the intensity turns to be more symmetrical, which exhibits a $<011>$ fiber texture along the BD. The orientation distribution function (ODF) in Figure 2.6 shows a clear transition from a texture component to a fiber texture as the level of scan rotation increasing, where the strongest fiber texture is found in the sample with $67^{\circ}$ scan rotation. A further investigation on the mechanical behaviors of different as-built texture can be found in Paper I. 

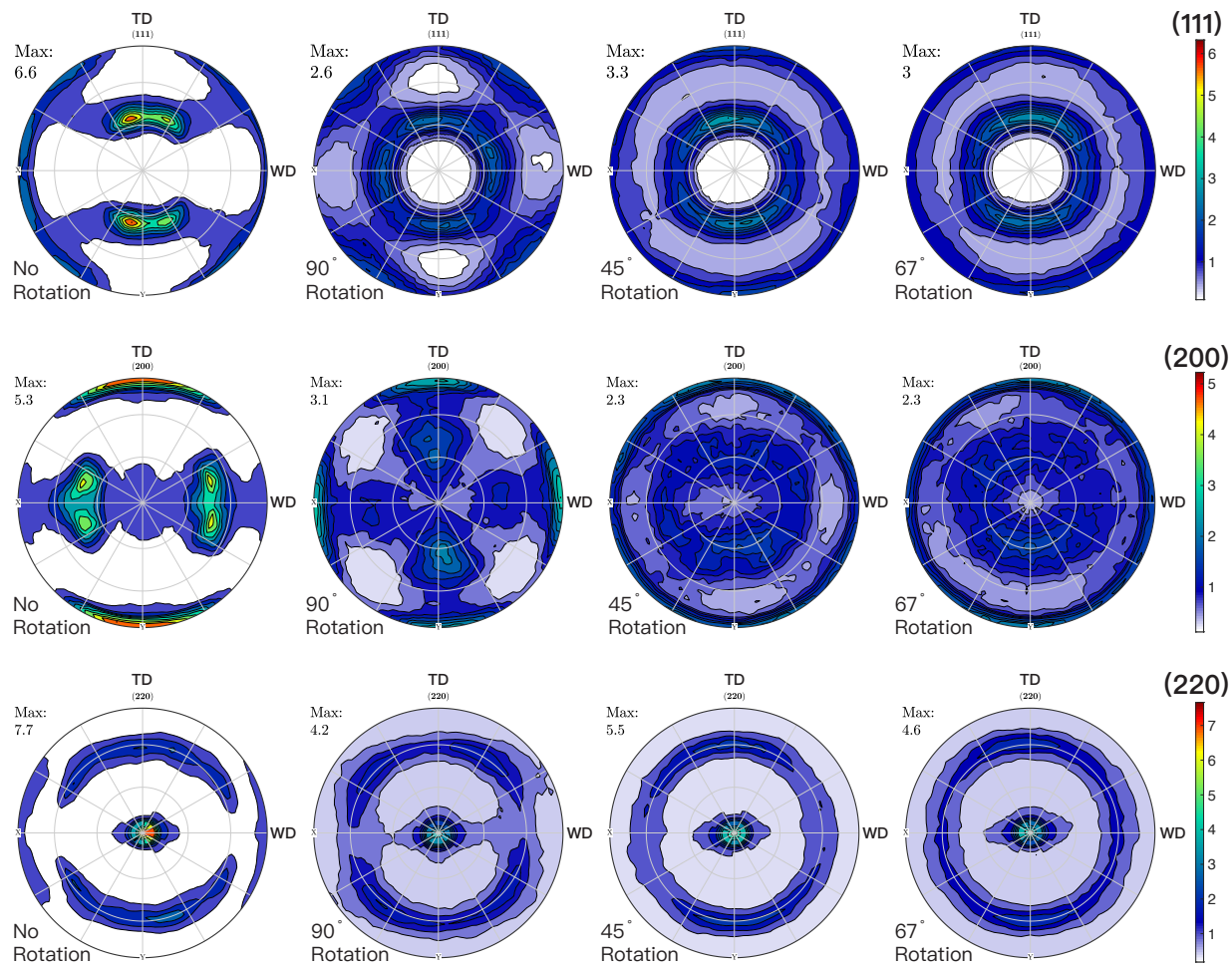

Figure 2.5. The (111), (200) and (220) pole figures of LPBF stainless steel 316L printed with different scan rotation, $0^{\circ}, 90^{\circ}, 45^{\circ}$ and $67^{\circ}$. The pole figures are measured from neutron diffraction. The center refers to the $\mathrm{BD}$, the vertical poles refer to the TD and the horizontal poles refer to the WD. The color legend is shared between the different samples with the same pole figure respectively. 


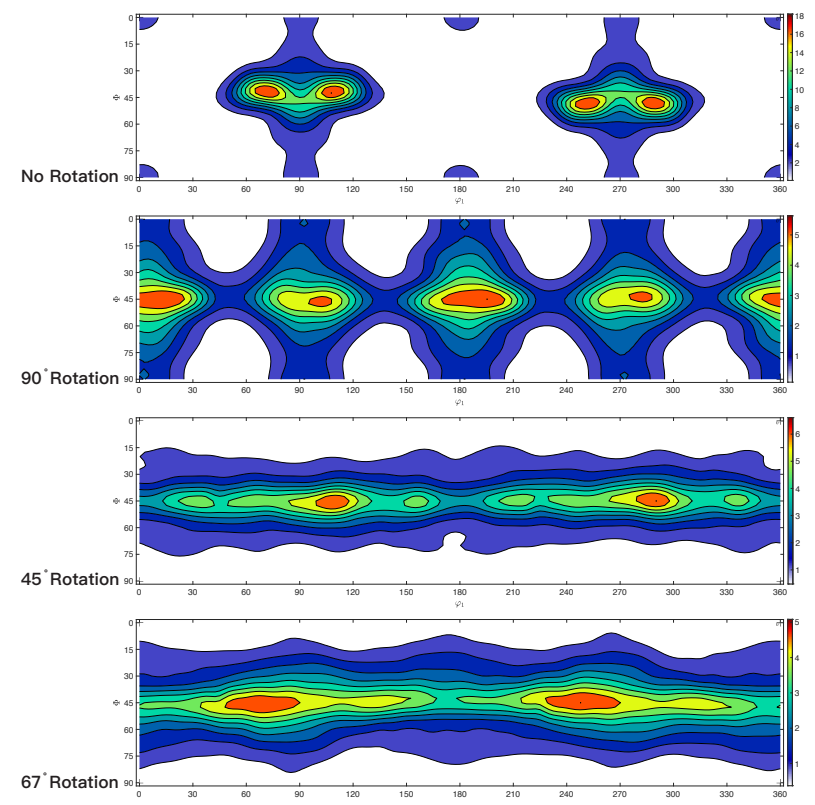

Figure 2.6. The orientation distribution function (ODF) of LPBF stainless steel 316L printed with different scan rotation, $0^{\circ}, 90^{\circ}, 45^{\circ}$ and $67^{\circ}$. Each ODF is reconstructed from five poles measured from neutron diffraction, including (111), (200), (220), (311) and (222).

\subsection{Thin-walled structure}

An important topic of this thesis is to investigate the thin-wall effects in LPBF materials. It is assumed that the geometrical variation will lead to different thermal boundary condition and result in the evolution of microstructure. Therefore, a set of plate-like specimens with different nominal thicknesses, $1 \mathrm{~mm}, 1.5 \mathrm{~mm}, 2 \mathrm{~mm}$, $2.5 \mathrm{~mm}$ and $4 \mathrm{~mm}$, are printed for microstructure and mechanical behavior study, where the flat dog-bone tensile testing specimens are taken directly from the plates by electrical discharge machining (EDM), see Figure 2.7. In addition, a rod-like specimen has been printed and set as a reference for the texture study, where the diameter is $18 \mathrm{~mm}$ and the length is $125 \mathrm{~mm}$. In order to conduct an universal study of the geometrical effect in LPBF, the standard printing parameters in EOS equipment are applied for a fair comparison to the other relevant research. 
(a)

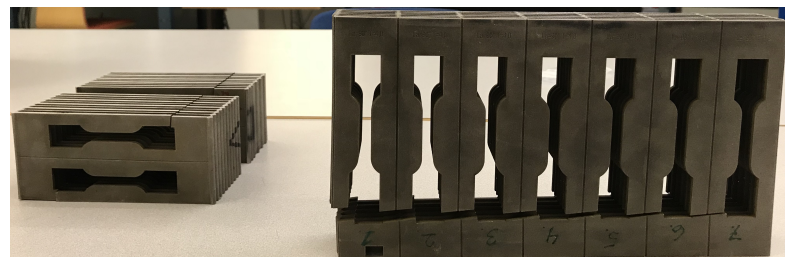

(b)

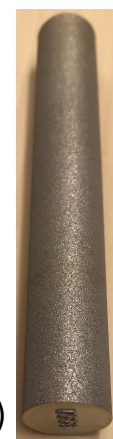

Figure 2.7. (a) The plate-like specimens of LPBF HX with different thicknesses, $1 \mathrm{~mm}$, $1.5 \mathrm{~mm}, 2 \mathrm{~mm}, 2.5 \mathrm{~mm}$ and $4 \mathrm{~mm}$. The dog-bone tensile testing specimens are taken directly from the plates by using EDM. (b) The reference group, rod-like specimen of LPBF HX with a diameter of $18 \mathrm{~mm}$ and a length of $125 \mathrm{~mm}$.

\subsubsection{Thickness and height-dependent}

To reveal the statistic microstructure behavior, the texture measurement by neutron diffraction has been carried out on both plate-like and rod-like specimens. The measured gauge volume for the plate-like specimen covered the entire thickness including the rough surface. For the rod-like specimens, the measured samples were taken from the bottom and the top, which represent the initial state and stable state of the printing process, and the samples were machined to the diameter of $10 \mathrm{~mm}$ and the height of $10 \mathrm{~mm}$ to show the "bulk texture".

Figure 2.8a shows the (200), (220) and (222) pole figures (PF) of each sample, and the sample coordinate system is the same as the one shown in Figure 2.3d. The texture of plate-like specimen exhibits a clear thickness-dependence. An approximate $<001>$ fiber texture along the TD is shown in $1 \mathrm{~mm}$ thick sample, and it becomes a $<011>$ fiber texture with weaker orientation along the BD in $4 \mathrm{~mm}$ thick sample. Fiber texture stands for a feature that a certain crystallographic orientation aligns toward a direction with respect to the sample coordinate system. Take the PFs of $4 \mathrm{~mm}$ for example, a strong point-like intensity locates at the center of (220) PF and ring-like intensities are found at different corresponding polar angles in each PF, which indicates a $<011>$ fiber texture. The $<001>$ and $<111>$ crystallographic orientations are randomly distributed with the axis of $<011>$ direction, hence, it results in a ring-like intensity in the PFs.

A comparison to the rod-like sample in Figure 2.8b can further reveal the geometrical effect since the thermal boundary condition is symmetric on the plane normal to the BD where the grain growth is expected to be homogeneous on the planar directions. However, ring-like intensity is not found in the PFs, instead, clear point-like intensities with two-fold symmetry appear. The texture of rodlike sample shows similarity with Goss texture $\{011\}<100>$, which is a texture commonly found in silicon-steel from rolling processes [44], and it has been reported in other LPBF Ni-based superalloy as well [43]. Yet, the spatial relation between the rod and the building chamber was not recorded and only the BD is known, so 
the effect such as the laser movement to the final texture remains unclear. On the other hand, the texture from the top of the build is stronger and sharper than the bottom of the build where the bottom is close to the base plate. Hence a slightly less identical microstructure caused by the unstable thermal field in the initial state of the printing is indicated. A further discussion correlating the microstructure and statistic texture can be found in Paper III.

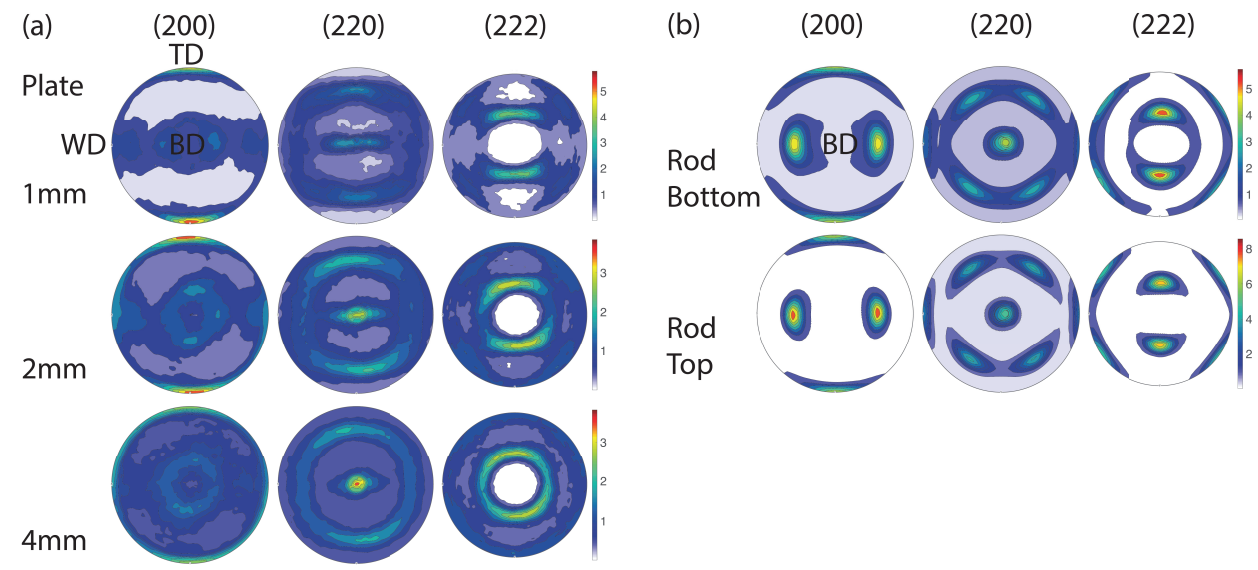

Figure 2.8. The (200), (220) and (222) pole figures of the as-built specimens in Figure 2.7. The pole figures are obtained from neutron diffraction, and the color legend is shared by the three pole figures of each specimen respectively. (a) The plate-like specimens. The center refers to the $\mathrm{BD}$, the vertical poles refer to the TD and the horizontal poles refer to the WD. (b) The rod-like specimens. The center refers to the BD. The specimen is built from the bottom to the top, hence, the bottom is close to the base plate.

\subsubsection{Surface roughness}

It is common to find rough surface in the as-built LPBF and EBM materials due to the unmelted and semi-melted powders attached on the surface as shown in Figure 2.3a. The surface roughness can cause stress concentration and be detrimental to mechanical properties, such as fatigue [45-47]. In addition, the surface roughness also influences the size of measured net cross-section that carries the loading, which is the primary concern in this study. With the thinner sample, the proportion of surface roughness in the entire cross-section becomes larger. Given that the attached powder at the surface has no contribution to the loading bearing, a crosssection calibration method is proposed by reducing a selected surface roughness parameter. The selection of proper surface roughness parameter is demonstrated in Paper III. This method can be applied when the length of a certain dimension is close to the minimum limit. 


\section{CHAPTER 3}

\section{Deformation and fracture mechanisms}

To bring AM in high temperature applications such as gas turbine, it is necessary to examine the mechanical properties at elevated temperatures. Tensile tests from room temperature up to $700{ }^{\circ} \mathrm{C}$ have been carried out on the flat dog-bone specimens shown in Figure 2.7. Two types of tensile specimen were set for the anisotropy study, one was the "Vertical" where the loading direction (LD) was applied along the $\mathrm{BD}$, and the other one was "Horizontal" where the LD was applied perpendicular to the $\mathrm{BD}$. The mechanical behavior under different strain rates at $700{ }^{\circ} \mathrm{Chas}$ also been investigated with the comparison to a wrought HX set as a reference group of conventional manufacturing.

Anisotropic mechanical properties are commonly found in AM materials where the strength along the BD is slightly weaker than the TD [36, 37, 48]. This thesis studies the anisotropic mechanical behavior with different influencing factors. The influence of temperature variation will be discussed in Paper II and Paper III, where a ductile to brittle transition and a weakening trend of anisotropy at elevated temperature have been traced. The specimen thickness also plays an important role as a clear texture difference has been found, and the texture evolution will be discussed in Paper III and Paper IV. Finally, the influence of strain rate at 700 ${ }^{\circ} \mathrm{C}$ will be discussed in Paper IV after a discovery of ductility transition. Multiple factors result in the mechanical behaviors, and each of them will be discussed in the following sections.

\subsection{Anisotropic mechanical behaviors}

The stress-strain curves in Figure 3.1 reveal the anisotropic mechanical behaviors where the yield strength, ultimate tensile strength (UTS) and work hardening of the horizontal tests are better than the vertical test. However, the vertical ductility 
outperforms the horizontal ductility, especially at $700{ }^{\circ} \mathrm{C}$, the horizontal ductility shows a significant drop while the vertical ductility remains at the same level as the lower temperature tests. A further investigation at $700{ }^{\circ} \mathrm{C}$ by using slow strain rate testing (SSRT) is shown in Figure 3.2. A continuous softening right after the yield point is present in both vertical and horizontal tests. In addition, a further drop of horizontal ductility is found in both the strain rate of $10^{-5} \mathrm{~s}^{-1}$ and $10^{-6}$ $\mathrm{s}^{-1}$.

(a)
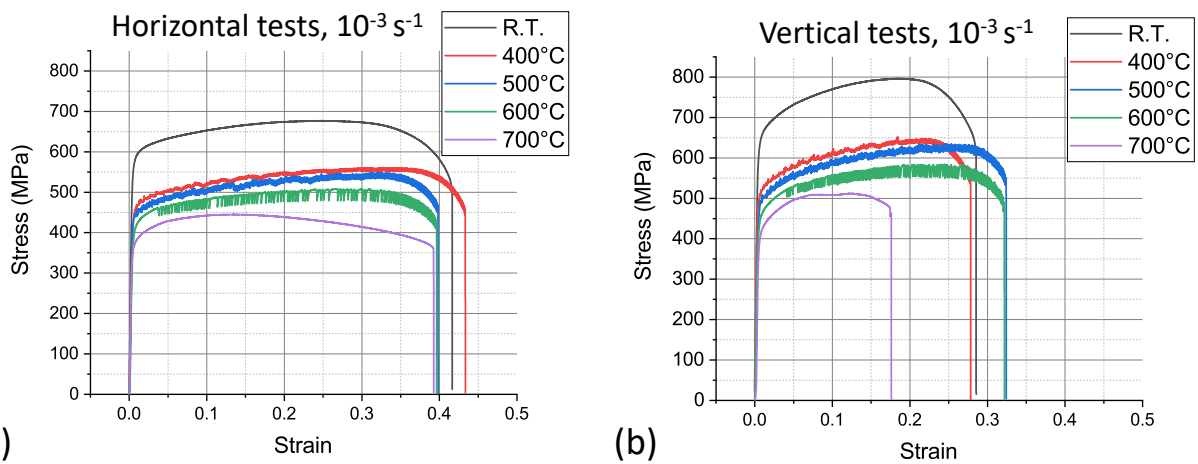

Figure 3.1. Tensile stress-strain curves of LPBF HX at elevated temperatures with the strain rate of $10^{-3} \mathrm{~s}^{-1}$. (a) The vertical tests. (b) The horizontal tests.

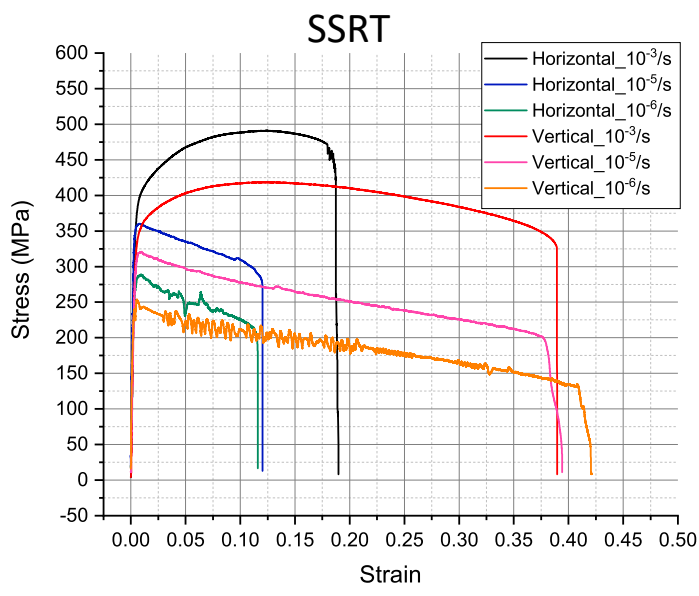

Figure 3.2. Slow strain rates tensile testing of LPBF HX at $700{ }^{\circ} \mathrm{C}$. Three different strain rates are compared, including $10^{-3} \mathrm{~s}^{-1}, 10^{-5} \mathrm{~s}^{-1}$ and $10^{-6} \mathrm{~s}^{-1}$.

\subsection{Grain morphology effect}

The elongated grain and cell structure shown in Figure 2.3 is an important factor contributing to the anisotropic mechanical behavior. A simplified schematic 
illustration of the LD and the grain structure is proposed in Figure 3.3, where the green elongated grains represent the major $<011>$ texture component and the red part stands for the minor $<001>$ texture component along the BD. For the horizontal tests, as the loading is applied on the longitudinal side of the elongated grain, it is relatively easier for the grain boundary detachment to take place and results in lower ductility. Grain boundary of Ni-based superalloys is supposed to be stable at elevated temperatures, however, the increasing creep damage and weaker chemical bonding [49] from intermediate to high temperature embrittle the grain boundary. The enhancement of grain boundary embrittlement from $500{ }^{\circ} \mathrm{C}$ to $700{ }^{\circ} \mathrm{C}$ is clearly indicated from the fracture surface study shown in Paper II, and the further time-dependent creep damage can be found in the SSRT study in Paper IV. For the vertical tests, the elongated grains are approximately along the BD in the as-built state, and they will align further closer to the BD after the deformation, for which a discussion of grain rotation can be found in Paper III and Paper IV.

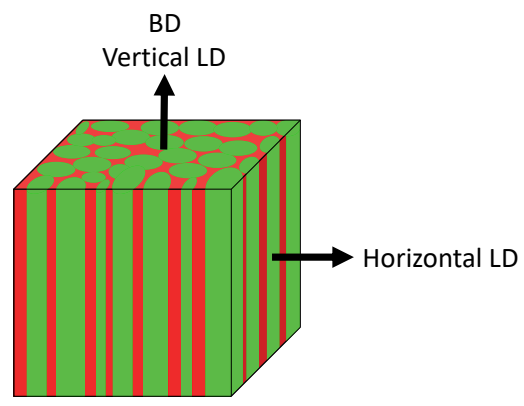

Figure 3.3. Schematic illustration of the spatial relationship between the LD and the grain structure. The green elongated grains refer to the major $<011\rangle$ texture component along the $\mathrm{BD}$, and the red elongated grains refer to the minor $<001>$ texture component along the BD.

\subsection{Dislocation movement and texture strengthen- ing}

Dislocation is an important crystallographic defect in crystalline metallic materials since the plastic deformation usually undergoes via the movement of dislocation. Dislocation is a linear crystallographic defect or irregular atomic arrangement, which can be categorized into two major types, edge dislocation and screw dislocation. There are different types of dislocation movement at various conditions, such as planar slip, cross-slip and climb, and the planar slip will be discussed first [50].

For most of the crystallographic metals, the slip of dislocation takes place on the densest lattice plane with the direction pointing toward the shortest distance between atoms, hence, the $<011>\{111\}$ is the favorable slip system for materials with FCC crystallographic structure [51]. To activate a slip, the shear stress on 
a slip system needs to reach critical value, $\tau_{c}$, which is often named as critical resolved shear stress (CRSS), and the spatial relationship between the applied load and slip system is determined by Schmid's law in equation 3.1 [52],

$$
\tau_{c}=\sigma_{x} \cos \lambda \cos \phi
$$

where $\sigma_{x}$ is the stress of the uniaxial load, $\lambda$ is the angle between slip direction and load direction, $\phi$ is the angle between slip plane normal and load direction. However, the LPBF material is not a single crystal, the polycrystal deformation behavior has to be taken into consideration. As proposed by G. I. Taylor [53], the deformation of each grain in polycrystal needs to be compatible with the neighbor grains, so the shape change of each grain should be the same as the entire polycrystal. In Taylor's assumption, the critical shear stress causing the slip is the same on all active system, and for the case of FCC crystals, each grain with different orientation experiences the deformation consisted of the summation of 5 out of 12 shear strain, which is the 5 lowest shear strain in the $<011>\{111\}$ slip system. The external applied stress and the internal shear stress can be determined with the Taylor's factor by equation 3.2 ,

$$
\sigma_{x}=M \tau
$$

where $\sigma_{x}$ is the external uniaxial tension, $\mathrm{M}$ is the Taylor's factor and $\tau$ is the shear stress. Slip is easier to be activated in orientation-favorable grain, so crystallographic texture plays a key role in anisotropic mechanical properties where the yield strength is a direct indication [54,55]. The orientation-dependence of Taylor's factor is computed and plotted in Figure 3.4 under the axisymmetric deformation of FCC crystals [50, 56], and the average Taylor's factor of all orientations is 3.067 which represents a FCC polycrystal with random texture. To analyze the anisotropy in this study, the Taylor's factors of the plate-like samples with different thickness and the rod-like samples are calculated from the pole figures shown in Figure 2.8, and the strain tensor is applied corresponding to the vertical and horizontal loading in this study with axisymmetric flow, see Figure 3.5. With different texture in the as-built state of each specimen, the stronger texture shows larger anisotropy of Taylor's factor between the vertical and horizontal loading conditions, which means that the top of the rod-like specimen shows the largest difference. The correlation between the yield strength and calculated Taylor's factor can be found in Paper III. 


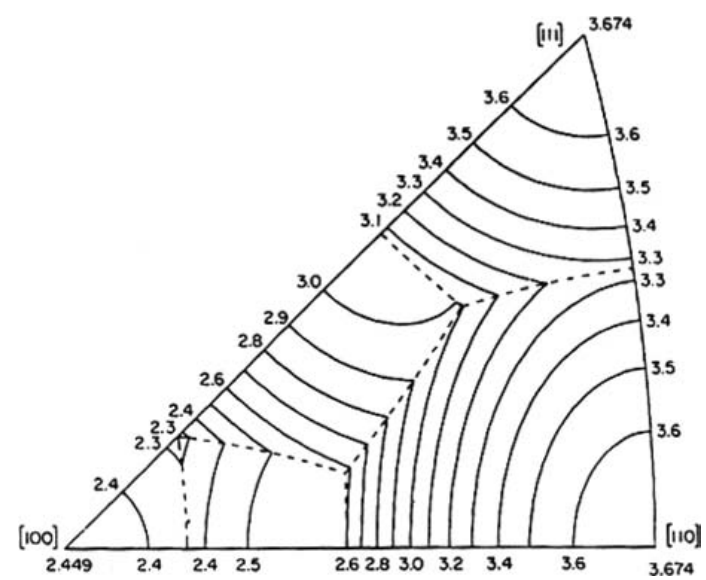

Figure 3.4. Computed orientation dependence of Taylor's factor for FCC crystals undergoing axisymmetric deformation reprinted from G. Y. Chin et al. [50, 56].

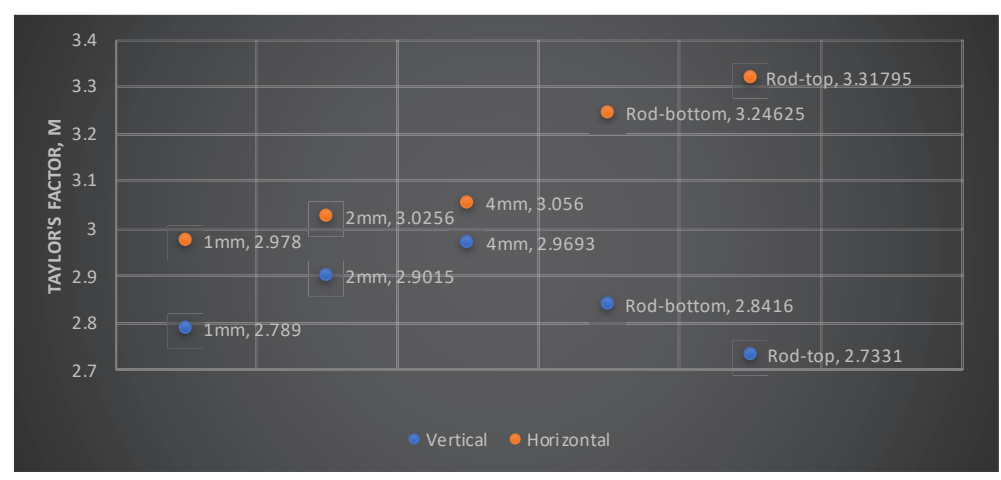

Figure 3.5. Calculated Taylor's factor for the plate-like and rod-specimens, with the strain tensor of axisymmetric flow corresponding to the vertical and horizontal loading condition. The calculation is based on the ODF, which is reconstructed from five pole figures measured by neutron diffraction.

The major difference between edge dislocation and screw dislocation is the movement mechanism [50]. Edge dislocation can only move on the unique slip plane that contains its Burgers vector, but screw dislocation is parallel to its Burgers vector and it can change from one slip plane to another. For edge dislocation to change slip plane, it needs a process called "climb" with the assistance of diffusional flux of atoms, and climb becomes is important at elevated temperature during creep deformation since it provides an alternative mechanism to avoid obstacle [57]. When a screw dislocation slips from one plane to another plane, the process is called "cross-slip", which is an energy-favorable way to pass through hindrance. A screw dislocation can dissociate into two partial dislocations and create a stacking fault in between, which can lower the total energy, but the partial 
dislocations need to recombine to form screw dislocation if it tends to cross-slip to another plane. The recombination of partial dislocations is not energy-favorable since it increases the total energy, which is aided by the applied stress and thermal activation, and the stacking fault energy determines the difficulty of the process [58]. The higher the stacking fault energy the lower applied stress it needs to cause the recombination, hence, the slip trace is wavy in metals with high stacking fault, for instance aluminum, due to the more frequently happening cross-slip; for the opposite case the slip trace is straight in metals with low stacking fault, for instance copper [50, 59-61]. However, it is even more complicated in the real cases, different partial dislocation movement can be found in the literature [18, 62][18], [62]. At high temperature, multiple slip systems and mechanisms can be activated, so the anisotropy such as the texture-dependent mechanical behavior becomes weaker [63].

\subsection{Texture evolution}

Lattice rotation often occurs gradually during the slip of dislocation, and it will lead to different crystallographic textures along the loading direction after deformation, depending on the crystal system and the loading condition. For example in FCC crystals, the end preferred orientation of single crystals is $<112>$ after tensile deformation and $<110>$ after compressive deformation. In addition, the end preferred orientations for polycrystals are mostly the same as single crystals, however, the end preferred orientations under tensile deformation become $<110>$ and $<111>$ for the case of FCC polycrystals. As tensile deformation mechanism of FCC crystals is the major interest in this study, the following discussion will focus on the texture evolution of the vertical and horizontal tensile loading in LPBF materials. 

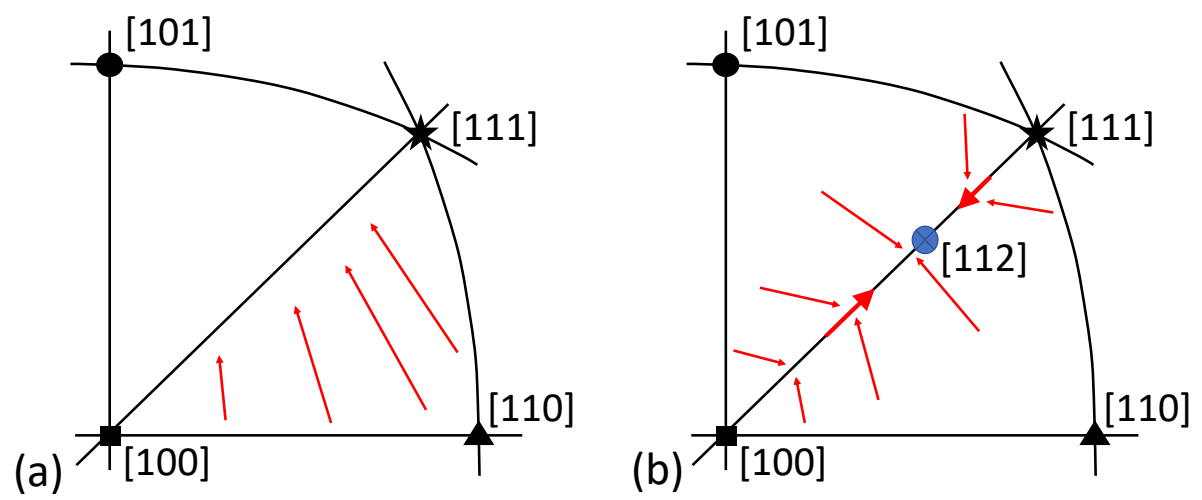

Figure 3.6. The texture evolution of FCC single crystals under tensile deformation adapted from W. F. Hosford [50]. (a) The primary slip system is activated and the texture evolves toward the [101] corner in the adjacent triangle. (b) When the texture reaches the [100]-[111] boundary, the favorable slip system in the adjacent triangle will be activated, which the texture tends to evolve toward [110] corner in the original triangle. The two conjugate slip systems are equivalent along the [100]-[111] boundary, and the end preferred orientation will evolves toward [112].

The evolution of preferred orientation in tension of FCC single crystals is schematically illustrated in Figure 3.6. With the consideration of the primary slip system $\{111\}<011>$ and given a basic stereographic triangle with [100], [110] and [111] at the corners, the texture will evolve toward the [101] corner in the adjacent triangle. When the texture passes through the [100]-[111] boundary of the triangle, the conjugate slip system will be activated, and the texture will evolve back to the [110] corner of the original triangle. The two conjugate slip systems are in competitive relationship while the texture being on the [100]-[111] boundary, and the texture moving gradually toward the end preferred orientation along the boundary [50].

To trace the texture evolution in this study, texture analysis by using neutron diffraction has been carried out on the sample with different deformation level, see Figure 3.7. Like the different mechanical behavior in the stress-strain curves, the vertical loading exhibits a significantly different texture evolution with higher level of change compared to the horizontal loading. For the vertical loading, a clear texture evolution toward the [100]-[111] boundary in the inverse pole figure (IPF) of $\mathrm{BD}$ is shown at the half-deformed point $(\Delta \epsilon=19.5 \%)$, and it further splits into two texture components, $<112>$ and $<001>$, at the fully deformed point. The end preferred orientation of $\langle 112>$ indicates that the deformation behavior of the vertical loading is similar to single crystals. However, less lattice rotation is expected in the horizontal loading since the deformed textures are rather close to the as-built state, and the deformation behavior shows similarity to polycrystals due to the end preferred orientations of $<001>$ and $<111>$. 
(a)

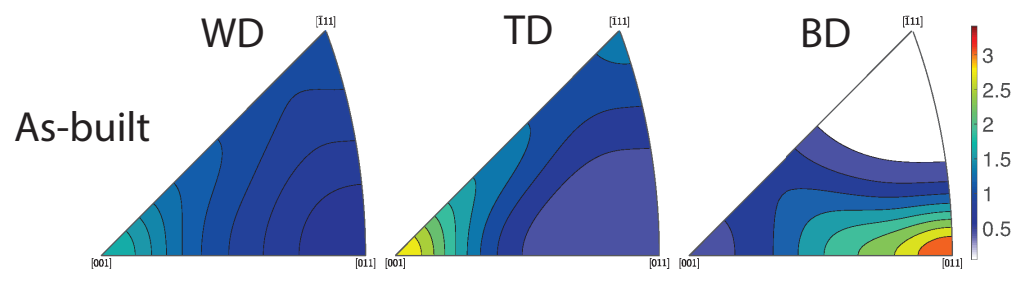

(b)

\section{Horizontal}
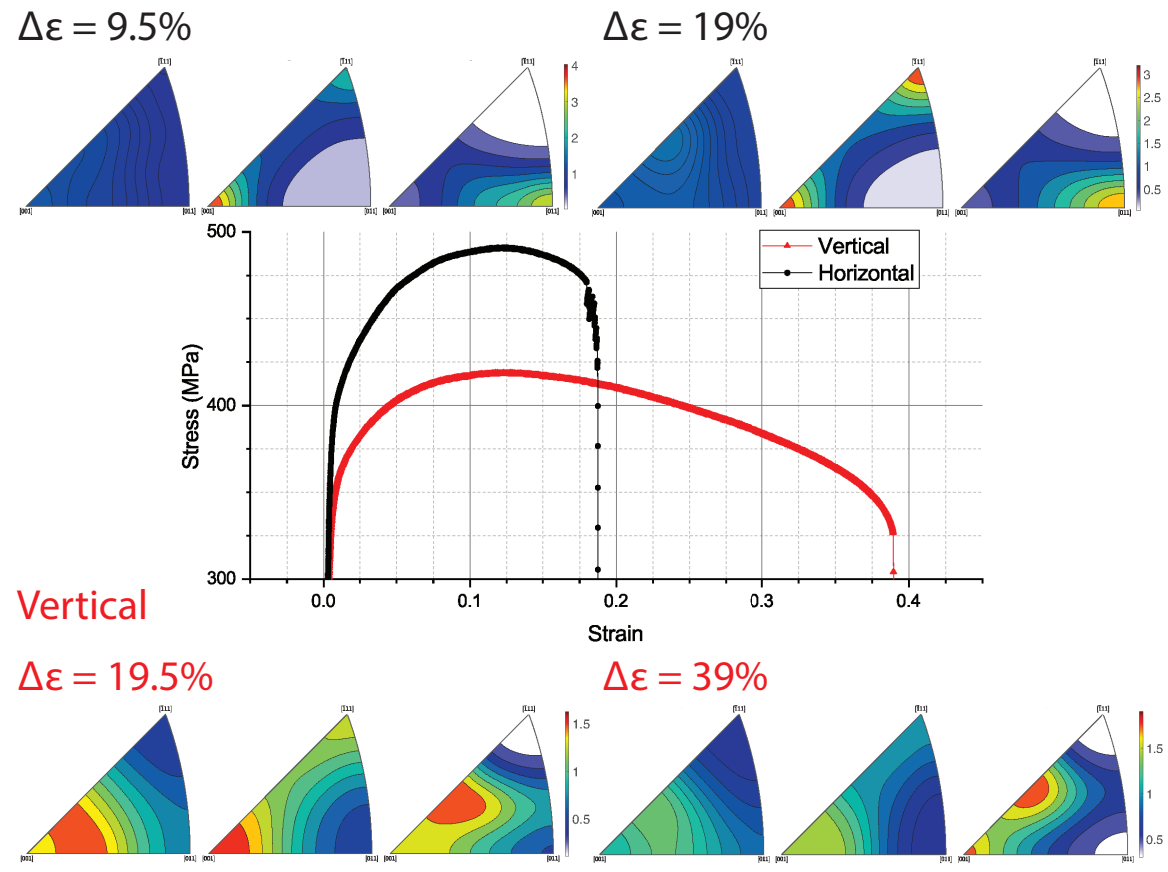

Figure 3.7. Inverse pole figures reconstructed from five pole figures obtained by neutron diffraction, with respect to the WD, TD and BD. (a) As-built texture. (b) Texture evolution under tensile deformation at different strain level at $700{ }^{\circ} \mathrm{C}$.

In addition, the initial state of the texture has a great influence on the texture evolution, see Figure 3.8. As a strong $<001>$ texture component exists along the TD in $1 \mathrm{~mm}$ as-built sample, the end preferred orientation stays at $<001>$ along the TD even though the $\mathrm{LD}$ has been applied on the $\mathrm{BD}$, which is quite different compared to the $4 \mathrm{~mm}$ deformed sample. A further discussion on the grain structure evolution under the lattice rotation, the effects of temperature and strain rates can be found in Paper III and Paper IV. 
(a) WD

TD

BD

WD

TD

BD



$1 \mathrm{~mm}$



Vertical

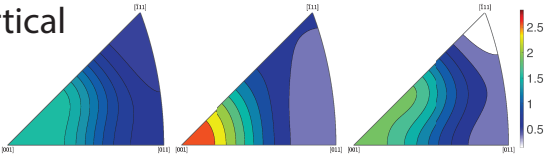

Horizontal
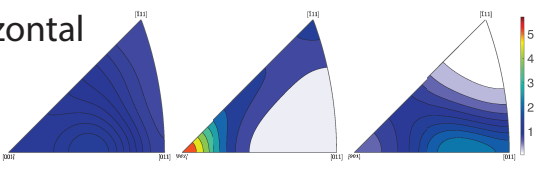

(b) WD

TD

$\mathrm{BD}$

TD

$\mathrm{BD}$

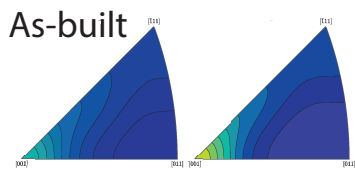

$4 \mathrm{~mm}$

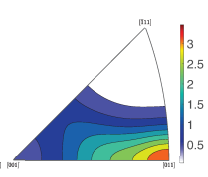

Vertical
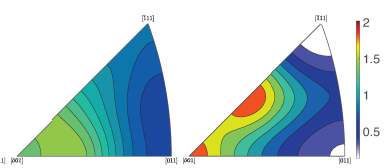

Horizontal
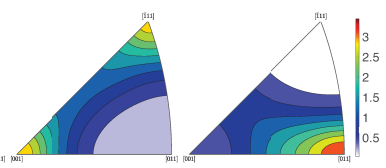

Figure 3.8. Inverse pole figures reconstructed from five pole figures obtained by neutron diffraction, with respects to the $\mathrm{WD}, \mathrm{TD}$ and $\mathrm{BD}$. The as-built texture and the fully deformed texture of different loading condition at $700{ }^{\circ} \mathrm{C}$ are shown. (a) Texture evolution of $1 \mathrm{~mm}$ plate-like specimen under tensile deformation. (b) Texture evolution of $4 \mathrm{~mm}$ plate-like specimen under tensile deformation.

\subsection{Deformation twinning}

Twin is a feature in crystals that the orientation of a certain region of lattice is mirror-symmetric to the neighbor lattice with a specific angular relationship. Twinning is also a deformation mechanism for metals, especially acting as an important alternative for hexagonal close-packed (HCP) metals due to the limited number of easily activated slip systems. There are two common types of twins, annealing twins are created during recrystallization, and deformation twins are formed by uniform shearing [50]. For conventionally manufactured HX, it is possible to observe annealing twins in the as-received material, and the annealing twins play a good role in hindering the dislocation movement during deformation [64-66], but it is not within the discussion in this study since annealing twins were not observed in LPBF HX.

Deformation twinning is caused by shear stress where the twinning occurs on $\{111\}$ planes and $<11 \overline{2}>$ directions, and the direction of the twinning shear is strict, so for example, the (111)[11르 shear can cause deformation twinning but not the opposite direction (111)[112]. The lattice rotation of deformation twinning is abrupt and it can be considered as a nucleation and growth process [67]. The local 
stress concentration are important nucleation sites for deformation twinning, where the response of dislocation to the local concentration plays a decisive role. For example, Lomer-Cottrell lock of partial dislocations [68], the dislocation reaction in the region of grain boundaries $[69,70]$ and the microtwinning when partial dislocations encounter precipitation [71]. The mechanisms of dislocation reaction for triggering deformation twinning are complicated and there are more different scenarios in the literature.

The tendency of materials to twin depends on several factors, for instance, temperature, strain rate, grain size, texture and stacking fault energy [67, 72, 73]. In general, for FCC materials, the lower temperature and lower strain rate are favorable for the formation of deformation twins, while the stacking fault energy is an even more important factor where the tendency to twin increases with lower stacking fault energy. Stacking fault energy is highly composition dependent. For Ni-based superalloys, the stacking fault energy for pure $\mathrm{Ni}$ is $125 \mathrm{~mJ} / \mathrm{m}^{2}$ [58], each element in Ni-based superalloy exhibits different level of influence [74], and Mo serves as a leading factor in HX in this study due to the high potential to lower the stacking fault energy [75]. Besides, the texture also plays a significant role, for example, it is more common to observe deformation twins in grains with $<111>$ orientations along the LD rather than the slip favorable $<001>$ oriented grains in twinning-induced plasticity (TWIP) steel [76]. A further discussion on the favorable texture for deformation twinning in LPBF materials can be found in Paper IV.

\subsection{Creep damage}

Creep is a time-dependent plastic deformation behavior that is composed of multiple temperature-dependent mechanisms, and creep damage becomes significant at high temperature, which is needed to be taken into consideration in the slow strain rate tensile testing in this study.

A creep test is carried out on a material usually with constant applied engineering stress (constant load) and temperature, and creep behavior can be divided into three stages shown in Figure 3.9. At the first stage, the material reacts elastically as the load being applied, followed by a transformation to plastic deformation with rapid strain rate. Then the strain rate gradually decreases to a steady-state where the second stage starts. Finally, the strain rate increases again at the third stage due to the shrinkage of cross-section and the possible porosity and cavitation development in the tertiary creep. 


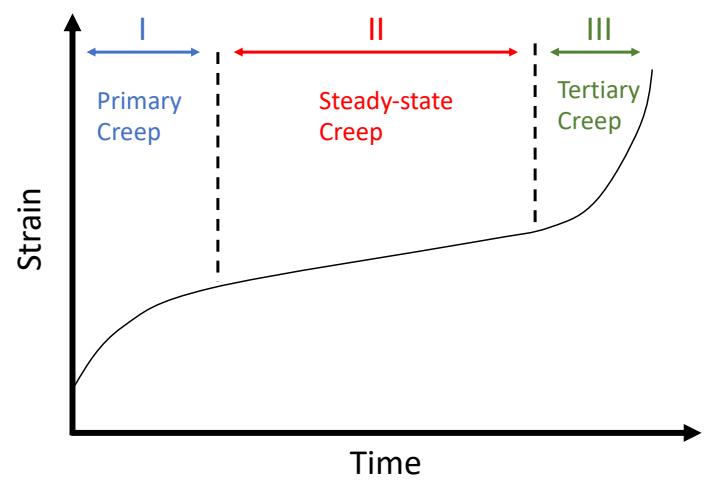

Figure 3.9. Schematic illustration of time-dependent creep deformation behavior, which is consisted of three stages, primary creep, steady-state creep and tertiary creep.

Creep deformation can be described as viscous flow of which the viscosity depends on the thermal activation energy. In polycrystals, the grain boundary sliding facilitates the viscous flow, at the same time, the compatibility among grains is maintained by the diffusional flow, dislocation movement and grain boundary migration [50]. The tensile stress separates the atoms in the grain boundaries, and it becomes a driving force for the diffusional flow that the atoms diffuse from the grain boundaries parallel to the stress axis to the grain boundaries normal to the stress axis. The atomic diffusion can either pass through the lattice (NabarroHerring creep, particularly at high temperature) or along grain boundaries (Coble creep, particularly at low temperature). The various dislocation movement can also dominate the creep deformation, for instance, the diffusion-assisted climb of dislocation is activated at high temperature, and the obstruction to the partial dislocation movement by the precipitation in Ni-based superalloy. Multiple factors contribute to the strain rate, including the mentioned above, and the overall strain rate is led by the most rapid mechanism. The overall steady-state creep strain rate is often described as follow in equation $3.3[18,77,78]$,

$$
\dot{\varepsilon}=A \sigma^{n} \exp \frac{-Q}{R T}
$$

where $\dot{\epsilon}$ is the strain rate, $\mathrm{A}$ is a constant, $\sigma$ is the applied stress, $\mathrm{n}$ is the stress exponent, $\mathrm{R}$ is ideal gas constant, and $\mathrm{T}$ is the temperature. $\mathrm{Q}$ is the activation energy deduced from the experimental data, it refers to all the mechanisms mentioned above, and it often correlate with activation energy for self-diffusion. Given an applied stress and temperature, one can estimate the rupture time of a creep test from the experimental data itself by using different assumptions, such as Sherby-Dorn, Monkman-Grant relationship and Larson-Miller parameter.

As mentioned earlier that creep deformation can be seen as a viscous flow, which includes grain rotation. Hence, texture shows a great influence on the creep behavior since a grain responds differently depending on its orientation, for instance, the different level of grain rotation and texture evolution [63, 79], and the favorable orientation for deformation twinning [80]. A further study on the 
creep damage in LPBF materials from the SSRT study can be found in Paper IV. 


\section{CHAPTER 4}

\section{Experimental methods}

The main purpose of this study is to investigate the anisotropic material properties of thin-walled structure manufactured by LPBF. The study material is the platelike specimen with different thicknesses shown in Figure 2.7, and it is provided by Siemens Energy AB, Sweden. The experimentation details will be present in this chapter, including LPBF process parameters, mechanical test and microstructure analysis.

\subsection{Laser Powder Bed Fusion}

The study material was built with standard printing parameters in an EOS M290 machine, and the used powder was EOS NickelAlloy HX. The thickness of each building layer was set as $20 \mu \mathrm{m}$, and the $67^{\circ}$ scanning rotation was applied. In each building layer, the hatching was first and then followed by two times of the contouring with the width of $0.15 \mathrm{~mm}$. The material for the entire study was meant for as-built state, so no post treatment has been applied. Plate-like specimens with different nominal thicknesses, $1 \mathrm{~mm}, 1.5 \mathrm{~mm}, 2 \mathrm{~mm}, 2.5 \mathrm{~mm}$ and $4 \mathrm{~mm}$, were built and shown in Figure 2.7.

The reference group for this study, a wrought HX, has similar nominal composition as EOS NickelAlloy HX, and a solution annealing of 20 minutes at $1175{ }^{\circ} \mathrm{C}$ followed by water quenching was applied on the material.

\subsection{Mechanical test}

Tensile tests with the strain rate of $10^{-3} \mathrm{~s}^{-1}$ were carried out at room temperature and elevated temperatures, from $400{ }^{\circ} \mathrm{C}$ to $700{ }^{\circ} \mathrm{C}$; tensile tests with the strain rates 
of $10^{-5} \mathrm{~s}^{-1}$ and $10^{-6} \mathrm{~s}^{-1}$ were done at $700{ }^{\circ} \mathrm{C}$. Under the standard ISO $6892-$ 2 , the tensile tests were performed by using an Instron $5582-100 \mathrm{kN}$ universal testing machine with strain-control using an Instron $7361 \mathrm{C}$ extensometer where the gauge length was $12.5 \mathrm{~mm}$, and the tensile specimens were placed in a heating furnace with a type $\mathrm{K}$ thermocouple attached to the center of the specimen for the temperature control within the variation less than $\pm 2{ }^{\circ} \mathrm{C}$. The flat dog-bone tensile specimens with the dimensions given in Figure 4.1 were taken from the plate-like specimens by using electrical discharge machining (EDM). Two types of tensile specimen were conducted in each test condition, one was "Vertical" where the LD was applied along the BD, and another one was "Horizontal" where the $\mathrm{LD}$ was applied perpendicular to the BD.

Tensile test specimen



Figure 4.1. The dimensions of flat dog-bone tensile specimens.

\subsection{Microstructure characterization}

\subsubsection{Light optical microscope}

A light optical microscope, Leica DM6, was used for imagining the melt pool structure and the cross-section for roughness measurement. For the melt pool structure, the imagine was taken from the Twin-jetted TEM thin foil where the melt pool boundaries were etched during the electropolishing process. Another alternative to reveal the melt pool structure is to electro-etched the well-polished sample with the solution of 10 vol.\% oxalic acid and $10 \mathrm{~V}$ of the applied voltage [81].

\subsubsection{Scanning electron microscope}

A Hitachi SU 70 field emission scanning electron microscope (FE-SEM) equipped with an electron back scatter diffraction (EBSD) detector from Oxford Instrument was used for the microstructure analysis. Secondary electron (SE) and backscattered electron (BSE) modes were operated at $10 \mathrm{KV}$ for microstructure imagining, and EBSD was operated at 15 or $20 \mathrm{KV}$ for grain orientation mapping. The imagining parameters vary slightly under different circumstance where the details can 
be found in each appended paper. An open source MATLAB toolbox, MTEX, was used for EBSD data analysis [82].

For the metallographic preparation, the cross-section of interest was first cut by using EDM and mounted into an electrically conductive resin, PolyFast, from Struers. Then the sample was mechanically ground step-by-step from 500 Grit up to 4000 Grit and followed by fine polishing with diamond suspension from $3 \mu \mathrm{m}$ down to $0.25 \mathrm{\mu m}$. Finally, the sample was polished by using OP-U colloidal silicon suspension, and water was used as the last step to take away the residual particle from the suspension as much as possible.

\subsubsection{Transmission electron microscope}

The dislocation structure was studied by using transmission electron microscope (TEM), FEI Tecnai G2 microscope, operating at an accelerating voltage of 200 KV. The sample preparation of TEM thin foil started with grinding down to the thickness of $50-100 \mu \mathrm{m}$. To further thin down the sample below $100 \mathrm{~nm}$, ideally $30 \mathrm{~nm}$ for high resolution analysis, an electropolishing was applied by using Struers TenuPol-5 electrolytic machine. The solution was 10 vol.\% perchloric acid with 90 vol.\% ethanol, it was operated at the applied voltage of $23 \mathrm{~V}$ and ambient temperature of $-25^{\circ} \mathrm{C}$.

\subsection{Neutron diffraction}

The texture analysis of bulk materials was carried out by using KOWARI, a neutron diffractometer at ANSTO [83]. Each PF was measured by monochromatic beam with a wavelength of $1.5 \AA$ on an approximately $5 \times 5^{\circ}$ polar grid where the gauge volume covered the entire sample, and the measurement time per angular position was 5 seconds. Five PFs, (111), (200), (220), (311) and (222) were obtained and used for the reconstruction of orientation distribution function (ODF) for quantitative analysis. An open source MATLAB toolbox, MTEX, was used for texture analysis [84].

\subsection{Roughness determination}

The surface roughness was determined from the cross-section image analysis of the specimen by using an in-house MATLAB script [85]. The desired cross-section was cut and mounted, then multiple images was taken from a light optical microscope for statistical analysis. Different roughness parameters were calculated from the two-dimensional roughness analysis. The definition of each parameters from the standard ISO 4287 is schematically illustrated in Figure 4.2 , where $\mathrm{R}_{a}$ is the arithmetic mean values of the $\mathrm{Z}$-coordinates, $\mathrm{R}_{c}$ is the mean value of $\mathrm{Zt}_{i}$ in each $\mathrm{S}_{i}, \mathrm{R}_{p}$ is the mean value of $\mathrm{Zp}_{i}$ in each $\mathrm{S}_{i}, \mathrm{R}_{z}$ is the maximum $\mathrm{Zt}_{i}, \mathrm{R}_{v}$ is the maximum $\mathrm{Zv}_{i}$ and $\mathrm{R}_{q}$ is the root mean square of the $\mathrm{Z}$-coordinates. 


\section{Sample length, $\mathrm{L}$}

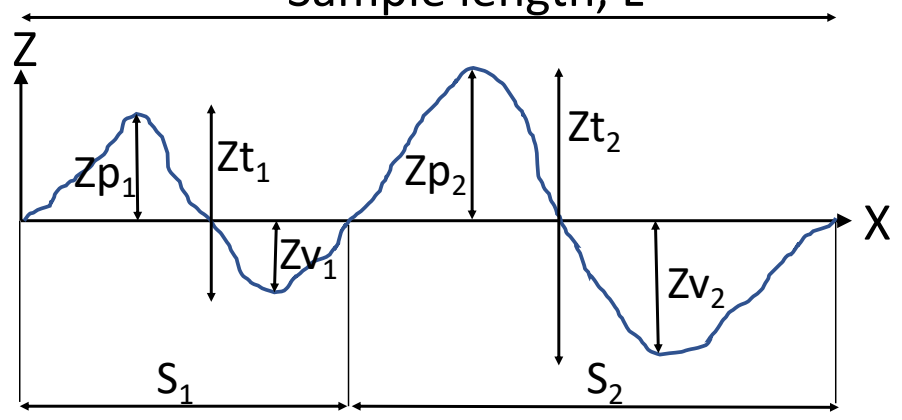

Figure 4.2. Schematic illustration of a roughness profile. 


\section{CHAPTER 5}

\section{Summary of the appended papers}

I. A. Leicht, C. H. Yu, V. Luzin, U. Klement, and E. Hryha, "Effect of scan rotation on the microstructure development and mechanical properties of 316L parts produced by laser powder bed fusion," Materials Characterization, vol. 163, p. 110309, 2020.

This paper serves as an initiation of this Licentiate thesis since the effect of scan rotation on the materials properties has been carried out, which is the primary concern of printing parameters influence on as-built microstructure and mechanical behavior of LPBF materials.

The degree of scan rotation refers to the angular relationship of the laser moving direction between each adjacent scanning layer. A comparison has been drawn among the samples applied with $0^{\circ}, 45^{\circ}, 67^{\circ}$ and $90^{\circ}$ scan rotation, and it turns out that the $67^{\circ}$ scan rotation gives relatively weaker mechanical properties (yield strength, UTS and ductility) but a more homogeneous grain structure at the same time. For the sample without scan rotation, a major texture component $<011>$ and a minor texture component $<001>$ along the $\mathrm{BD}$ is discovered along the $\mathrm{BD}$, and it becomes $<011>$ fiber texture along the $\mathrm{BD}$ as different level of scan rotation being applied. Scan rotation induces the randomness in the thermal field during the printing process, and it results in different level of anisotropic microstructure. The $67^{\circ}$ scan rotation is one of the standard printing parameters in an EOS M290 equipment, and the purpose is to decrease the anisotropic mechanical behavior by tuning to a more isotropic microstructure. However, even with the $67^{\circ}$ scan rotation, it is inevitable to observe elongated grain structure with specific texture along the BD. Therefore, the coming papers will investigate the influence of elongated grain structure on the mechanical behavior of LPBF materials. 
II. C.-H. Yu, R. L. Peng, J.-E. Lundgren, and J. Moverare, "Anisotropic mechanical properties of thin-walled Hastelloy X manufactured by laser powder bed fusion," European Congress and Exhibition on Powder Metallurgy, 2019.

This paper is the first study on the thin-walled Hastelloy X. Tensile tests with the strain rate of $10^{-3} \mathrm{~s}^{-1}$ have been carried out on the samples with different nominal thicknesses, $1 \mathrm{~mm}, 1.5 \mathrm{~mm}, 2 \mathrm{~mm}, 2.5 \mathrm{~mm}$ and $4 \mathrm{~mm}$, at room temperature and elevated temperatures, from $400{ }^{\circ} \mathrm{C}$ to $700{ }^{\circ} \mathrm{C}$. The anisotropic mechanical properties were verified by the vertical and horizontal tests shown in Figure 2.7.

The thickness-dependent mechanical properties are observed, where the thinner sample exhibits lower yield strength and UTS, but the ductility has no such tendency. The thickness-dependence is due to the overestimated crosssection that takes the load, and a cross-section calibration by reducing the surface roughness is proposed. The anisotropic mechanical properties are demonstrated by the higher yield strength and UTS in the horizontal tests and the better ductility in the vertical tests. At $700{ }^{\circ} \mathrm{C}$, the horizontal ductility has a clear drop while the vertical ductility remains at the same level as the lower temperatures, and a transition from ductile to brittle behavior at $700{ }^{\circ} \mathrm{C}$ is proved by the fracture surface observation.

III. C.-H. Yu, R. L. Peng, V. Luzin, M. Sprengel, M. Calmunger, J.-E. Lundgren, H. Brodin, A. Kromm, J. Moverare, "Thin-wall effect and anisotropic deformation mechanisms of an additively manufactured Ni-based superalloy," submitted manuscript.

This paper is a continuous study on the thin-walled Hastelloy $\mathrm{X}$ to further investigate the cross-section calibration method and the different deformation mechanism between the vertical and horizontal tests.

To verify multiple thickness-dependent factors, a microstructure study, surface roughness measurement, texture analysis and residual stress measurement have been carried out. The statistic texture analysis by using neutron diffraction reveals a clear texture transition from the $<011>$ fiber texture along the $\mathrm{BD}$ to the $<001>$ fiber texture along the TD when the thickness decreases. By combining the study of microstructure, melt pool structure and grain orientation maps, the average texture of an entire component can be deduced from the angular relationship between the elongated grain structure and the BD. Besides, since the rough surface of as-built LPBF component is inevitable in nature, a cross-section calibration method is developed with an assumption that the thickness-dependent yield strength is mainly related to the Taylor's factor. The Taylor's factor is calculated from the pole figures obtained by neutron diffraction, and it corresponds well with the decreasing tendency of yield strength as the sample becomes thinner, hence, a more precise cross-section estimation can be made by comparing the yield strength between different samples. The concerns of residual stress, dislocation density and grain size effect are ruled out by the result from XRD analysis since 
there is no thickness-dependence. Therefore, the cross-section calibration method by reducing roughness parameter $\mathrm{R}_{p}$ is proposed to obtain a more precise yield strength when the length of a dimension is close to minimum limit.

The elongated grain structure is responsible for the anisotropic mechanical properties. A further investigation of dislocation structure under TEM image also uncovers an elongated subgrain structure with dislocations piling up at grain boundaries, which is assumed to contribute to the anisotropy. Besides, the calculated Taylor's factors for the vertical and horizontal loading conditions show that the texture exhibits a great influence on the anisotropy. The deformation mechanism study is conducted by examining the microstructure and texture of the deformed sample. At room temperature and $700{ }^{\circ} \mathrm{C}$, a clear lattice rotation is found in the vertical tests, and the trace of texture evolution is similar to single crystals deformation behavior. On the other hand, the microstructure of horizontally deformed sample does not undergo significant change, and the texture evolution is similar to polycrystals.

This paper also makes a comparison to conventionally manufactured materials, a wrought HX, with consideration of the tensile mechanical behavior, grain structure and dislocation structure. The wrought HX exhibits lower yield strength but better work hardening and ductility, and the reason for the difference is due to the high dislocation density of LPBF HX at the asbuilt state. During the LPBF process, the high thermal gradient deforms and strengthens the material, hence, the yield strength is higher than the wrought HX but the work hardening capacity is consumed at the same time.

\section{C.-H. Yu, R. L. Peng, H. Brodin, and J. Moverare, "Anisotropic deformation and fracture mechanisms of an additively manufac- tured Ni-based superalloy," in TMS Superalloys 2020.}

This paper is a continuous study on the mechanical response of LPBF Hastelloy $\mathrm{X}$ to the elevated temperatures. Since a ductile to brittle transition is traced at $700{ }^{\circ} \mathrm{C}$, this work further investigates the mechanical behavior under different slow strain rates tensile testing at $700{ }^{\circ} \mathrm{C}$. The comparison is drawn among the three different strain rates, $10^{-3} \mathrm{~s}^{-1}, 10^{-5} \mathrm{~s}^{-1}$ and $10^{-6}$ $\mathrm{s}^{-1}$, and it is also compared with the mechanical behavior of a wrought HX. The strain rates of $10^{-5} \mathrm{~s}^{-1}$ and $10^{-6} \mathrm{~s}^{-1}$ are defined as slow strain rate.

At the strain rate of $10^{-3} \mathrm{~s}^{-1}$ and in the intermediate temperature region, a degradation of strength at higher temperature is shown, but the mechanical behaviors from $400{ }^{\circ} \mathrm{C}$ to $600{ }^{\circ} \mathrm{C}$ are similar. In addition, dynamic strain aging (DSA) is discovered, and a transition from type $\mathrm{A}$ to type $\mathrm{C}$ is traced from $400{ }^{\circ} \mathrm{C}$ to $600{ }^{\circ} \mathrm{C}$. The DSA behavior is slightly different between the vertical and horizontal tests, and it is assumed to be related to the elongated subgrain structure and the dislocations piling up at subgrain boundaries. Compared to conventionally manufactured $\mathrm{HX}$, the temperature region of the type $\mathrm{A}$ to type C DSA transition in LPBF $\mathrm{HX}$ is $50{ }^{\circ} \mathrm{C}-100^{\circ} \mathrm{C}$ lower. At $700{ }^{\circ} \mathrm{C}$, the level of work hardening decreases and the DSA does not occur, moreover, 
the horizontal ductility drop is found while the vertical ductility remains at the same level.

At $700{ }^{\circ} \mathrm{C}$ with the strain rates of $10^{-5} \mathrm{~s}^{-1}$ and $10^{-6} \mathrm{~s}^{-1}$, a degradation of strength with slower strain rate is shown, and softening right after the yield point occurs in both the vertical and horizontal tests. The horizontal ductility of both slow strain rates has a further drop with the same level while the vertical ductility still remains at the same level. The degradation of strength and the softening behavior are caused by creep damage. Creep voids are observed at grain boundaries, and they are responsible for the decrease of horizontal ductility. From the fracture surface study, the grain boundary embrittlement is more profound in the horizontal tests, and it also occurs in the vertical tests but depends on the angular relationship between the grain boundary and the LD.

The most interesting discovery is that deformation twins are observed and only in the vertical tests. Compared to other Ni-based superalloy, the tendency for deformation twinning to occur in HX is low due to the high stacking fault energy, and deformation twinning in conventionally manufactured HX has not been reported in the literature. The deformation twins are mostly found in the $<111>/ /$ LD oriented grains, which share similarity with the tensile behavior in TWIP steels and the creep behavior in single crystal Ni-based superalloys. It is assumed that the original $<011>/ / \mathrm{LD}$ oriented grains undergo lattice rotation toward $<111>$ crystallographic direction, and the deformation twinning takes place in the twinning favorable $<111>/ / \mathrm{LD}$ oriented grains with the assistance of stress concentration at grain boundaries. The larger level of lattice rotation and deformation twinning enable the vertical ductility to remain at high level even with creep damage. 


\section{CHAPTER 6}

\section{Conclusion}

This Licentiate thesis has systematically investigated the microstructure and tensile mechanical behavior of Hastelloy X manufactured by laser powder bed fusion. The following conclusions are drawn into four themes to answer the aims and research questions of this study.

\section{As-built microstructure}

- The directional laser energy input leads to elongated grain and subgrain structure, and the angular relation between the grain growth direction and the building direction leads to different average texture results.

- Scan rotation induces randomness in the thermal field during the printing process. As a result, a major $<011>/ /$ BD with a minor $<001>/ / B D$ texture component is shown in the sample without scan rotation, and it transfers to $<011>/ /$ BD fiber texture with applied scan rotation.

\section{Thin-walled effects}

- With a variation of thickness from $4 \mathrm{~mm}$ down to $1 \mathrm{~mm}$ of plate-like samples, a clear texture transition from $<011>/ /$ BD fiber texture to $<001>/ /$ TD fiber texture and a declination of calculated Taylor's factor are discovered as the thickness decreases. A reference group of rod-like sample shows a texture similar to Goss texture, but the mechanism for its formation remains unclear.

- The declination of calculated Taylor's factor corresponds well with the decreasing tendency of yield strength. A load bearing cross-section calibration method is proposed by reducing a roughness parameter $\mathrm{R}_{p}$.

- The different crystallographic texture in the as-built state leads to different texture evolution. 
- The residual stress of $4 \mathrm{~mm}$ and $1 \mathrm{~mm}$ sample is at the same level. A tensile residual stress around $90 \mathrm{MPa}$ along the BD is traced and it is nearly stress free along the TD.

\section{Tensile behavior at elevated temperatures and different slow strain rates}

- With the strain rate of $10^{-3} \mathrm{~s}^{-1}$, the work hardening behavior and ductility remain similar at different intermediate temperatures, from $400{ }^{\circ} \mathrm{C}$ to $600{ }^{\circ} \mathrm{C}$, but a degradation of yield strength and UTS is revealed with the elevated temperature. At $700{ }^{\circ} \mathrm{C}$, a ductile to brittle transition of fracture behavior is found, and it is more significant in the horizontal tests due to the grain boundary detachment.

- Dynamic strain aging is found between $400{ }^{\circ} \mathrm{C}$ and $600{ }^{\circ} \mathrm{C}$. A transition from type $\mathrm{A}$ to type $\mathrm{C}$ is shown but with lower temperature range compared to conventionally manufactured HX, and the absence of DSA at $700{ }^{\circ} \mathrm{C}$ is assumed to be related to the ductile to brittle transition.

- At $700{ }^{\circ} \mathrm{C}$ with the slow strain rates of $10^{-5} \mathrm{~s}^{-1}$ and $10^{-6} \mathrm{~s}^{-1}$, creep damage is found to cause the degradation of strength, the softening behavior right after the yield point and the grain boundaries embrittlement by forming creep voids. Deformation twinning is discovered only in the vertical tests, which occurs mostly in the twinning favorable $<111>/ /$ LD oriented grains, and it is beneficial for the vertical ductility to remain at high level even under creep damage.

- With a comparison between LPBF and wrought HX, the rapid cooling in the LPBF process induces high dislocation density and strengthens the material, but it also sacrifices the capacity for work hardening at the same time.

\section{Anisotropic mechanical behaviors}

- In general, the horizontal strength is higher while the vertical ductility is better. The strength difference is highly related to the as-built crystallographic texture since different critical shear stress is required depending on the loading condition. A large lattice rotation to support high ductility in the vertical test is found in each of the testing variations mentioned above. The vertical texture evolution is similar to the deformation mechanism of single crystals, yet the horizontal lattice rotation behavior is close to polycrystals.

- In the slow strain rates testing, deformation twinning is only discovered in the vertical tests, which occurs mostly in the twinning favorable $<111>/ /$ LD oriented grains, and it is beneficial for the vertical ductility to remain at high level even under creep damage. 


\section{CHAPTER 7}

\section{Future work}

The licentiate thesis is a halfway examination of the entire $\mathrm{PhD}$ research, and the plans for the next stage are proposed as follows.

\section{- In-situ neutron diffraction study}

It will be a continuous study on the anisotropic deformation mechanism at $700{ }^{\circ} \mathrm{C}$ under the slow strain rate conditions, $10^{-5} \mathrm{~s}^{-1}$ and $10^{-6} \mathrm{~s}^{-1}$. In-situ neutron diffraction is planned to be carried out on the sample during tensile testing, and the continuously recorded diffraction at evolving strain level is expected to give a better understanding of lattice rotation and deformation twinning process. A TEM work on the deformed sample is planned to investigate the dislocation movement, hence, a study with the combination of different scales will give a clearer picture of deformation mechanisms. Furthermore, it can be a good reference study for low cycle fatigue study and mechanical behavior simulation with the respect to crystal plasticity in the future.

- Fatigue behavior of LPBF stainless steel 316L with tubular structure

This is an on-going research on the low cycle fatigue behavior of LPBF stainless steel 316L. To reveal the thin-walled effect on the fatigue behavior, tubular fatigue specimens with different thicknesses of $1 \mathrm{~mm}$ and $2 \mathrm{~mm}$ and rough as-built surface are made. Two reference groups will be carried out, one is tubular fatigue specimen with polished surface, and another one is regular cylindrical fatigue bar. The fatigue deformation mechanism of LPBF stainless steel $316 \mathrm{~L}$ will be studied with a comparison to conventionally manufactured stainless steel 316L. 
From the point of view of functionality, the primary concern of engineering materials is the mechanical properties, especially the fatigue and creep properties since they determine the life time of a component and further influence the life cycle of an entire application. These two properties have been studied for a long time, but the knowledge in LPBF materials is very limited. Therefore, it motivates this $\mathrm{PhD}$ research to dig in the fatigue and creep behavior of LPBF materials based on the knowledge of monotonic tensile behavior in this Licentiate thesis. 


\section{Bibliography}

[1] Hideo Kodama. "Automatic method for fabricating a three- dimensional plastic model with photo- hardening polymer". In: Rev. Sci. Instrum. 52.June 1998 (1998), pp. 2-6.

[2] Ian Gibson, D W Rosen, and B Stucker. Additive manufacturing technologies : $3 D$ printing, rapid prototyping, and direct digital manufacturing. Second edi. Springer, 2015.

[3] Olov Andersson et al. "Developing Additive Manufacturing Technology for Burner Repair". In: J. Eng. Gas Turbines Power 139.3 (2016), p. 031506.

[4] L. Koester et al. "Additive manufacturing metrology: State of the art and needs assessment". In: AIP Conf. Proc. 1706.February (2016).

[5] Manyalibo J. Matthews et al. "Denudation of metal powder layers in laser powder bed fusion processes". In: Acta Mater. 114 (2016), pp. 33-42.

[6] B. Ferrar et al. "Gas flow effects on selective laser melting (SLM) manufacturing performance". In: J. Mater. Process. Technol. 212.2 (2012), pp. 355364.

[7] Camille Pauzon et al. "Effect of argon and nitrogen atmospheres on the properties of stainless steel 316L parts produced by laser-powder bed fusion". In: Mater. Des. 179 (2019).

[8] Amir M. Mirzendehdel and Krishnan Suresh. "Support structure constrained topology optimization for additive manufacturing". In: CAD Comput. Aided Des. (2016).

[9] G. Strano et al. "A new approach to the design and optimisation of support structures in additive manufacturing". In: Int. J. Adv. Manuf. Technol. (2013). 
[10] Yiğit M. Arısoy et al. "Influence of scan strategy and process parameters on microstructure and its optimization in additively manufactured nickel alloy 625 via laser powder bed fusion". In: Int. J. Adv. Manuf. Technol. 90.5-8 (2017), pp. 1393-1417.

[11] Ali Keshavarzkermani et al. "Controlling mechanical properties of additively manufactured hastelloy $\mathrm{X}$ by altering solidification pattern during laser powder-bed fusion". In: Mater. Sci. Eng. A 762.May (2019), p. 138081.

[12] A. Leicht et al. "Effect of scan rotation on the microstructure development and mechanical properties of $316 \mathrm{~L}$ parts produced by laser powder bed fusion". In: Mater. Charact. 163.March (2020), p. 110309.

[13] A. Leicht et al. "Effect of process parameters on the microstructure, tensile strength and productivity of 316L parts produced by laser powder bed fusion". In: Mater. Charact. 159.November 2019 (2020), p. 110016.

[14] Christopher U Brown et al. "The effects of laser powder bed fusion process parameters on material hardness and density for nickel alloy 625". In: NIST Adv. Manuf. Ser. (2018), pp. 100-119.

[15] Haynes International. Hastelloy \& X Alloy. 1997.

[16] T. Mukherjee et al. "Printability of alloys for additive manufacturing". In: Sci. Rep. 6 (2016), pp. 1-8.

[17] Edouard Chauvet et al. "Hot cracking mechanism affecting a non-weldable Ni-based superalloy produced by selective electron Beam Melting". In: Acta Mater. 142 (2018), pp. 82-94.

[18] Roger C Reed. The superalloys. fundamentals and applications. Cambridge University Press, 2006.

[19] Michael Cloots, Peter J. Uggowitzer, and Konrad Wegener. "Investigations on the microstructure and crack formation of IN738LC samples processed by selective laser melting using Gaussian and doughnut profiles". In: Mater. Des. 89 (2016), pp. 770-784.

[20] Roman Engeli et al. "Processability of different IN738LC powder batches by selective laser melting". In: J. Mater. Process. Technol. 229 (2016), pp. 484491.

[21] Luke N. Carter et al. "The influence of the laser scan strategy on grain structure and cracking behaviour in SLM powder-bed fabricated nickel superalloy". In: J. Alloys Compd. 615 (2014), pp. 338-347.

[22] Markus Ramsperger, Robert F. Singer, and Carolin Körner. "Microstructure of the Nickel-Base Superalloy CMSX-4 Fabricated by Selective Electron Beam Melting". In: Metall. Mater. Trans. A Phys. Metall. Mater. Sci. 47.3 (2016), pp. 1469-1480.

[23] Amrita Basak, Ranadip Acharya, and Suman Das. "Additive Manufacturing of Single-Crystal Superalloy CMSX-4 Through Scanning Laser Epitaxy: Computational Modeling, Experimental Process Development, and Process Parameter Optimization". In: Metall. Mater. Trans. A Phys. Metall. Mater. Sci. 47.8 (2016), pp. 3845-3859. 
[24] Amrita Basak and Suman Das. "Additive Manufacturing of Nickel-Base Superalloy René N5 through Scanning Laser Epitaxy (SLE) Material Processing, Microstructures, and Microhardness Properties". In: Adv. Eng. Mater. 19.3 (2017), pp. 1-10.

[25] Richard Hertzberg, Richard Vinci, and Jason Hertzberg. Deformation and Fracture Mechanics of Engineering Materials. Wiley, 1937.

[26] L. A. Gypen and A. Deruyttere. "Multi-component solid solution hardening - Part 2 Agreement with experimental results". In: J. Mater. Sci. 12.5 (1977), pp. 1034-1038.

[27] H. A. Roth, C. L. Davis, and R. C. Thomson. "Modeling solid solution strengthening in nickel alloys". In: Metall. Mater. Trans. A Phys. Metall. Mater. Sci. 28.6 (1997), pp. 1329-1335.

[28] R. W. Kozar et al. "Strengthening mechanisms in polycrystalline multimodal nickel-base superalloys". In: Metall. Mater. Trans. A Phys. Metall. Mater. Sci. 40.7 (2009), pp. 1588-1603.

[29] Matthew J Donachie. "Superalloys: A Technical Guide, 2nd Edition". In: America (NY). (2002).

[30] Cheng-Han Yu et al. "Anisotropic mechanical properties of thin-walled Hastelloy X manufactured by laser powder bed fusion". In: Eur. Congr. Exhib. Powder Metall. Eur. PM Conf. Proc. 2019, pp. 0-5.

[31] J Zhao, M Larsen, and V Ravikumar. "Phase precipitation and time temperature-transformation diagram of Hastelloy X". In: Mater. Sci. Eng. A 293 (2000), pp. 112-119.

[32] Maria L. Montero-Sistiaga et al. "Effect of temperature on the microstructure and tensile properties of micro-crack free hastelloy $\mathrm{X}$ produced by selective laser melting". In: Addit. Manuf. 31.December 2019 (2020), p. 100995.

[33] T. DebRoy et al. "Additive manufacturing of metallic components - Process, structure and properties". In: Prog. Mater. Sci. 92 (2018), pp. 112-224.

[34] Andrew T. Polonsky et al. "Solidification-driven orientation gradients in additively manufactured stainless steel". In: Acta Mater. 183 (2020), pp. 249260.

[35] Minh Son Pham et al. "The role of side-branching in microstructure development in laser powder-bed fusion". In: Nat. Commun. 11.1 (2020), pp. 112 .

[36] Dunyong Deng et al. "Microstructure and mechanical properties of Inconel 718 produced by selective laser melting: Sample orientation dependence and effects of post heat treatments". In: Mater. Sci. Eng. A 713.December 2017 (2018), pp. 294-306.

[37] Dunyong Deng et al. "Microstructure and anisotropic mechanical properties of EBM manufactured Inconel 718 and effects of post heat treatments". In: Mater. Sci. Eng. A 693.December 2016 (2017), pp. 151-163. 
[38] Johannes A. Koepf et al. "3D multi-layer grain structure simulation of powder bed fusion additive manufacturing". In: Acta Mater. 152 (2018), pp. 119 126.

[39] R. R. Dehoff et al. "Crystallographic texture engineering through novel melt strategies via electron beam melting: Inconel 718". In: Mater. Sci. Technol. (United Kingdom) 31.8 (2015), pp. 939-944.

[40] Maria L Montero-sistiaga et al. "Microstructure and mechanical properties of Hastelloy X produced by HP-SLM ( high power selective laser melting )". In: Mater. Des. 165.2019 (2020), p. 107598.

[41] Zhongji Sun et al. "Simultaneously enhanced strength and ductility for 3Dprinted stainless steel 316L by selective laser melting". In: NPG Asia Mater. 10.4 (2018), pp. 127-136.

[42] Shi-hai Sun et al. "Excellent mechanical and corrosion properties of austenitic stainless steel with a unique crystallographic lamellar microstructure via selective laser melting". In: Scr. Mater. 159 (2019), pp. 89-93.

[43] Dong Ma et al. "Crystallographic texture in an additively manufactured nickel-base superalloy". In: Mater. Sci. Eng. A 684.September 2016 (2017), pp. 47-53.

[44] S. Mishra, C. Därmann, and K. Lücke. "On the development of the goss texture in iron-3\% silicon". In: Acta Metall. 32.12 (1984), pp. 2185-2201.

[45] M. Kahlin et al. "Improved fatigue strength of additively manufactured Ti6Al4V by surface post processing". In: Int. J. Fatigue 134.January (2020), p. 105497.

[46] M. Kahlin, H. Ansell, and J. J. Moverare. "Fatigue behaviour of additive manufactured Ti6Al4V, with as-built surfaces, exposed to variable amplitude loading". In: Int. J. Fatigue 103 (2017), pp. 353-362.

[47] M. Kahlin, H. Ansell, and J. J. Moverare. "Fatigue behaviour of notched additive manufactured Ti6Al4V with as-built surfaces". In: Int. J. Fatigue 101 (2017), pp. 51-60.

[48] Beth E. Carroll, Todd A. Palmer, and Allison M. Beese. "Anisotropic tensile behavior of Ti-6Al-4V components fabricated with directed energy deposition additive manufacturing". In: Acta Mater. 87 (2015), pp. 309-320.

[49] R. P. Messmer and C. L. Briant. "The role of chemical bonding in grain boundary embrittlement". In: Acta Metall. 30.2 (1982), pp. 457-467.

[50] William F. Hosford. Mechanical behavior of materials. 2005.

[51] Richard W. Hertzberg. Deformation and Fracture Mechanics of Engineering. 1996.

[52] Erich Schmid. "No Title". In: Proc. Internat. Cong. Appl. Mech. 1924.

[53] Geoffrey Ingram Taylor. "No Title". In: J. Inst. Met. 1938, p. v. 62. 
[54] R.P. Dalal, C.R. Thomas, and L.E. Dardi. "The effect of crystallographic orientation on the physical and mechanical properties of an investment cast single crystal nickel-base superalloy". In: TMS-AIME Superalloys (1984), pp. 185-197.

[55] R. V. Miner et al. "Orientation and Temperature Dependence of Some Mechanical Properties of the Single-Crystal Nickel-Base Superalloy Rene N4: Part Iii. Tension-Compression Anisotropy." In: Metall. Trans. A, Phys. Metall. Mater. Sci. 17 A.3 (1986), pp. 507-512.

[56] GY Chin and WL Mammel. "Computer solutions of taylor analysis for axisymmetric flow". In: Trans. Metall. Soc. AIME (1967).

[57] J Weertman. "Creep of indium, lead and some of their alloys". In: Trans. Metall. Soc. AIME (1960).

[58] J. P. Hirth, J. Lothe, and T. Mura. "Theory of Dislocations (2nd ed.)" In: J. Appl. Mech. (1983).

[59] L. Deléhouzée and A. Deruyttere. "The stacking fault density in solid solutions based on copper, silver, nickel, aluminium and lead". In: Acta Metall. (1967).

[60] P. C.J. Gallagher. "The influence of alloying, temperature, and related effects on the stacking fault energy". In: Metall. Trans. (1970).

[61] Farghalli A. Mohamed and Terence G. Langdon. "The transition from dislocation climb to viscous glide in creep of solid solution alloys". In: Acta Metall. (1974).

[62] D. P. Pope and S. S. Ezz. " Mechanical properties of Ni 3 AI and nickel-base alloys with high volume fraction of $\gamma^{\prime}$ ". In: Int. Mater. Rev. (1984).

[63] M. G. Ardakani et al. "Implications of dislocation micromechanisms for changes in orientation and shape of single crystal superalloys". In: Scr. Mater. 39.4-5 (1998), pp. 465-472.

[64] Wael Z. Abuzaid et al. "Slip transfer and plastic strain accumulation across grain boundaries in Hastelloy X". In: J. Mech. Phys. Solids 60.6 (2012), pp. 1201-1220.

[65] Wael Z Abuzaid et al. "Localisation of plastic strain at the microstructurlal level in Hastelloy $\mathrm{X}$ subjected to monotonic , fatigue, and creep loading : the role of grain boundaries and slip transmission Localisation of plastic strain at the micr". In: Mater. High Temp. 3409 (2016), pp. 1-17.

[66] W Abuzaid et al. "Fatigue crack initiation in Hastelloy X - the role of boundaries". In: (2013), pp. 809-826.

[67] J. W. Christian and S. Mahajan. "Deformation twinning". In: Prog. Mater. Sci. 39.1-2 (1995), pp. 1-157.

[68] J. B. Cohen and J. Weertman. A dislocation model for twinning in f.c.c. metals. 1963. 
[69] Jin Sung Hong et al. "The mechanism of mechanical twinning near grain boundaries in twinning-induced plasticity steel". In: Scr. Mater. 174 (2020), pp. $62-67$.

[70] I. Gutierrez-Urrutia and D. Raabe. Grain size effect on strain hardening in twinning-induced plasticity steels. 2012.

[71] L. Kovarik et al. "Microtwinning and other shearing mechanisms at intermediate temperatures in Ni-based superalloys". In: Prog. Mater. Sci. 54.6 (2009), pp. 839-873.

[72] M. A. Meyers, O. Vöhringer, and V. A. Lubarda. "The onset of twinning in metals: A constitutive description". In: Acta Mater. 49.19 (2001), pp. 40254039 .

[73] M. A. Meyers et al. "Dependence of tensile deformation behavior of TWIP steels on stacking fault energy, temperature and strain rate". In: Acta Mater. 60.6 (2009), pp. 2135-2145.

[74] Donald J. Siegel. "Generalized stacking fault energies, ductilities, and twinnabilities of Ni and selected Ni alloys". In: Appl. Phys. Lett. 87.12 (2005), pp. 13.

[75] S. L. Shang et al. "Effects of alloying element and temperature on the stacking fault energies of dilute Ni-base superalloys". In: J. Phys. Condens. Matter 24.50 (2012).

[76] S. Dancette et al. "Crystal plasticity modeling of texture development and hardening in TWIP steels". In: Acta Mater. 60.5 (2012), pp. 2135-2145.

[77] F. R. N. Nabarro and H. L. de Villiers. The Physics of Creep. Taylor \& Francis, 1995.

[78] P M Burke and O D Sherby. "Mechanical Behavior of Crystalline Solids at Elevated Temperature." In: Prog. Mater. Sci. (1968).

[79] L. M. Pan, B. A. Shollock, and M. Mclean. "Modelling of high-temperature mechanical behaviour of a single crystal superalloy". In: Proc. R. Soc. A Math. Phys. Eng. Sci. 453.1963 (1997), pp. 1689-1715.

[80] Jean Briac le Graverend et al. "Mechanical twinning in Ni-based single crystal superalloys during multiaxial creep at $1050^{\circ} \mathrm{C}^{\prime}$. In: Mater. Sci. Eng. A 722.December 2017 (2018), pp. 76-87.

[81] Mattias Calmunger et al. "Effect of additive manufacturing on fatigue crack propagation of a gas turbine superalloy". In: Procedia Struct. Integr. 23.2019 (2019), pp. 215-220.

[82] Florian Bachmann et al. "Inferential statistics of electron backscatter diffraction data from within individual crystalline grains". In: J. Appl. Crystallogr. 43.6 (2010), pp. 1338-1355.

[83] Alain Brule and Oliver Kirstein. "Residual stress diffractometer KOWARI at the Australian research reactor OPAL: Status of the project". In: Phys. B Condens. Matter 385-386 (2006), pp. 1040-1042. 
[84] R. Hielscher and H. Schaeben. "A novel pole figure inversion method: Specification of the MTEX algorithm". In: J. Appl. Crystallogr. 41.6 (2008), pp. 1024-1037.

[85] Sören Sjöström et al. "TBC bond coat-top coat interface roughness: Influence on fatigue life and modelling aspects". In: Surf. Coatings Technol. 236 (2013), pp. 230-238. 
50

Future work 


\section{Part II}

\section{Publications}





\section{Papers}

The papers associated with this thesis have been removed for copyright reasons. For more details about these see:

http://urn.kb.se/resolve?urn=urn:nbn:se:liu:diva-169054 


\section{INSTITUTE OF TECHNOLOGY}

Linköping Studies in Science and Technology, Licentiate Thesis No. 1884, 2020 Department of Management and Engineering

Linköping University

SE-581 83 Linköping, Sweden

www.liu.se 